\title{
Genomic characterization of two novel pathogenic avipoxviruses isolated from pacific shearwaters (Ardenna spp.)
}

\author{
Subir Sarker ${ }^{1 *}$ (D), Shubhagata Das ${ }^{2}$, Jennifer L. Lavers ${ }^{3}$, Ian Hutton ${ }^{4}$, Karla Helbig ${ }^{1}$, Jacob Imbery ${ }^{5}$, Chris Upton ${ }^{5}$
} and Shane R. Raidal ${ }^{2}$

\begin{abstract}
Background: Over the past 20 years, many marine seabird populations have been gradually declining and the factors driving this ongoing deterioration are not always well understood. Avipoxvirus infections have been found in a wide range of bird species worldwide, however, very little is known about the disease ecology of avian poxviruses in seabirds. Here we present two novel avipoxviruses from pacific shearwaters (Ardenna spp), one from a Flesh-footed Shearwater (A. carneipes) (SWPV-1) and the other from a Wedge-tailed Shearwater (A. pacificus) (SWPV-2).

Results: Epidermal pox lesions, liver, and blood samples were examined from A. carneipes and A. pacificus of breeding colonies in eastern Australia. After histopathological confirmation of the disease, PCR screening was conducted for avipoxvirus, circovirus, reticuloendotheliosis virus, and fungal agents. Two samples that were PCR positive for poxvirus were further assessed by next generation sequencing, which yielded complete Shearwaterpox virus (SWPV) genomes from A. pacificus and A. carneipes, both showing the highest degree of similarity with Canarypox virus ( $98 \%$ and $67 \%$, respectively). The novel SWPV-1 complete genome from A. carneipes is missing 43 genes compared to CNPV and contains 4 predicted genes which are not found in any other poxvirus, whilst, SWPV-2 complete genome was deemed to be missing 18 genes compared to CNPV and a further 15 genes significantly fragmented as to probably cause them to be non-functional.

Conclusion: These are the first avipoxvirus complete genome sequences that infect marine seabirds. In the comparison of SWPV-1 and -2 to existing avipoxvirus sequences, our results indicate that the SWPV complete genome from A. carneipes (SWPV-1) described here is not closely related to any other avipoxvirus genome isolated from avian or other natural host species, and that it likely should be considered a separate species.
\end{abstract}

Keywords: Avipoxvirus, Poxvirus, Next generation sequencing, dermatitis, Ardenna, Shearwater

\section{Background}

The Avipoxvirus genus includes a divergent group of viruses that cause diseases in more than 278 species of wild and domestic birds in terrestrial and marine environments worldwide $[1,2]$. Relatively little is known about the origins, worldwide host distribution and genetic diversity of avipoxviruses [3]. In affected birds, avipoxviruses typically cause proliferative 'wart-like' growths that are most commonly restricted to the eyes, beak or unfeathered skin of

\footnotetext{
* Correspondence: s.sarker@latrobe.edu.au

'Department of Physiology, Anatomy and Microbiology, School of Life

Sciences, La Trobe University, Melbourne, VIC 3086, Australia

Full list of author information is available at the end of the article
}

the body (so-called 'dry' pox), but infections can also develop in the upper alimentary and respiratory tracts ('wet' or 'diptheritic' pox) [2]. The incubation period and magnitude of avipoxvirus infection is variable, and is rarely fatal although secondary bacterial or fungal infections are common and cause increased mortality [2]. Such conditions in naïve populations can reach a much higher prevalence with substantial fatality $[4,5]$.

Avipoxviruses belong to the subfamily Chordopoxvirinae (ChPV) of the Poxviridae family, which are relatively large double-stranded DNA (dsDNA) viruses that replicate in the cytoplasm of infected cells [6]. Although poxviruses have evolved to infect a wide range of host species, to date 
only six avipoxvirus genomes have been published; a pathogenic American strain of Fowlpox virus (FPVUS) [7], an attenuated European strain of Fowlpox virus (FP9) [8], a virulent Canarypox virus (CNPV) [9], a pathogenic South African strain of Pigeonpox virus (FeP2), a Penguinpox virus (PEPV) [3], and a pathogenic Hungarian strain of Turkeypox virus (TKPV) [10]. Although these genome sequences demonstrate that avipoxviruses have diverged considerably from the other chordopoxviruses (ChPVs), approximately 80 genes have been found to be conserved amongst all ChPVs and to comprise the minimum essential poxvirus genome [11]. These genes tend to be present in the central core of the linear genome with the remainder presumed to be immunomodulatory and host specific genes located towards the terminal regions of the genome [3]. With the exception of TKPV (188 kb), avipoxvirus genomes $(266-360 \mathrm{~kb})$ tend to be bigger than those of other ChPVs due in part to multiple families of genes.

Over the past two decades, the status of the world's bird populations have deteriorated with seabirds declining faster than any other group of birds [12]. On Lord Howe Island in eastern Australia, the Flesh-footed Shearwater Ardenna carneipes has been declining for many years and is therefore listed as Vulnerable in the state of New South Wales [13]. The ongoing threat of plastic pollution, and toxicity from the elevated concentration of trace elements such as mercury could be confounding drivers of this declining species [14]. Infectious diseases, including those caused by avipoxviruses, have also been identified as an important risk factor in the conservation of small and endangered populations, particularly in island species [15-18]. The impact of the introduction of avipoxviruses has been severe for the avifauna of various archipelagos [19]. The emergence of distinctive avipoxvirus with a high prevalence $(88 \%)$ in Hawaiian Laysan Albatross (Phoebastria immutabilis) enabled one of the first detailed studies of the epidemiology and population-level impact of the disease in the seabirds [20]. However, relatively little is known about the general prevalence or effects of poxviruses in seabird species, including for shearwaters (Ardenna or Puffinus spp.). Therefore, the aim of the present study was to identify and characterize pathogens associated with clinical disease in breeding colonies of Flesh-footed Shearwater and Wedge-tailed Shearwater sourced from Lord Howe Island in 2015.

\section{Results}

\section{Identification of fungal pathogens}

In the sample from $A$. pacificus (15-1526, and 15-1527), there were multifocal areas of inflammation and exudation associated with serocellular surface crust that contained abundant branching fungal hyphae and aggregations of bacteria (Fig. 1c). A PCR screening was conducted for the presence of fungal pathogen using the ITS region to amplify a segment of approximately $550 \mathrm{bp}$. Two samples (out of 6) were positive for fungal pathogens, and direct Sanger sequencing of the purified gel bands resulted in a 550 bp sequence after trimming off primer sequences (data not shown). These sequences were further verified using high-throughput NGS, and generated con tigs of 3,430 bp (15-1526; GenBank accession KX857213) and 5,188 bp (15-1527; GenBank accession KX857212). A BLASTn search for the bird coinfected with fungal pathogen (15-1526) returned multiple hits to various fungal species, all with very similar scores; however, the best match $(88 \%)$ was to the Phaeosphaeria nodorum (GenBank Accession EU053989.1, and value $\leq \mathrm{e}-153$ ), a major necrotrophic fungal pathogen of wheat [21]. Similar search model for the fungal pathogen of bird 15-1527, demonstrated a highest hit (96\%) to the Metarhizium anisopliae var. anisopliae (GenBank Accession AY884128.1, and value $\leq \mathrm{e}-173$ ), an entomopathogenic fungus [22].

\section{Identification of virus}

Samples from six shearwater chicks of two different species, $A$. carneipes and $A$. pacificus, with evidence of gross well circumscribed, popular, crusting lesions across the feather skins (Fig. 1a), were biopsied, with blood and liver samples also collected. Histological examinations of the skin demonstrated focal to diffuse full thickness necrosis of the epidermis and a thick serocellular surface crust. A marked heterophilic rich inflammatory cellular response and exudation was present alongside abundant macrophages and perifollicular fibroplasia. In some areas there was focal proliferation of the adjacent epidermis associated with ballooning degeneration of keratinocytes with eosinophilic intracytoplasmic inclusions (Fig. 1b). A PCR screening was conducted for the presence of poxvirus, circovirus and reticuloendotheliosis virus, which are likely to cause this type of skin lesions. Two birds (A. pacificus 15-1526 and A. carneipes 15-1528) were positive by PCR targeting the $4 \mathrm{~b}$ gene that encodes a core protein of ChPV, however, there were no evidence of either circovirus or reticuloendotheliosis for any of the samples used in this study. Direct Sanger sequencing of the purified gel bands resulted in a 578 bp sequence after trimming off primer sequences (data not shown). A BLASTn search with these sequences returned multiple hits to the $4 \mathrm{~b}$ core gene from a variety of poxviruses, all with very similar scores; however, the best match was to the Canarypox virus $4 \mathrm{~b}$ core protein gene ((bird 15-1526; similarity with AY318871 was 99\% and identity score $\leq \mathrm{e}-162$ ), and bird 15-1528; similarity with LK021654 was 99\% and identity score $\leq \mathrm{e}-157)$ ). 


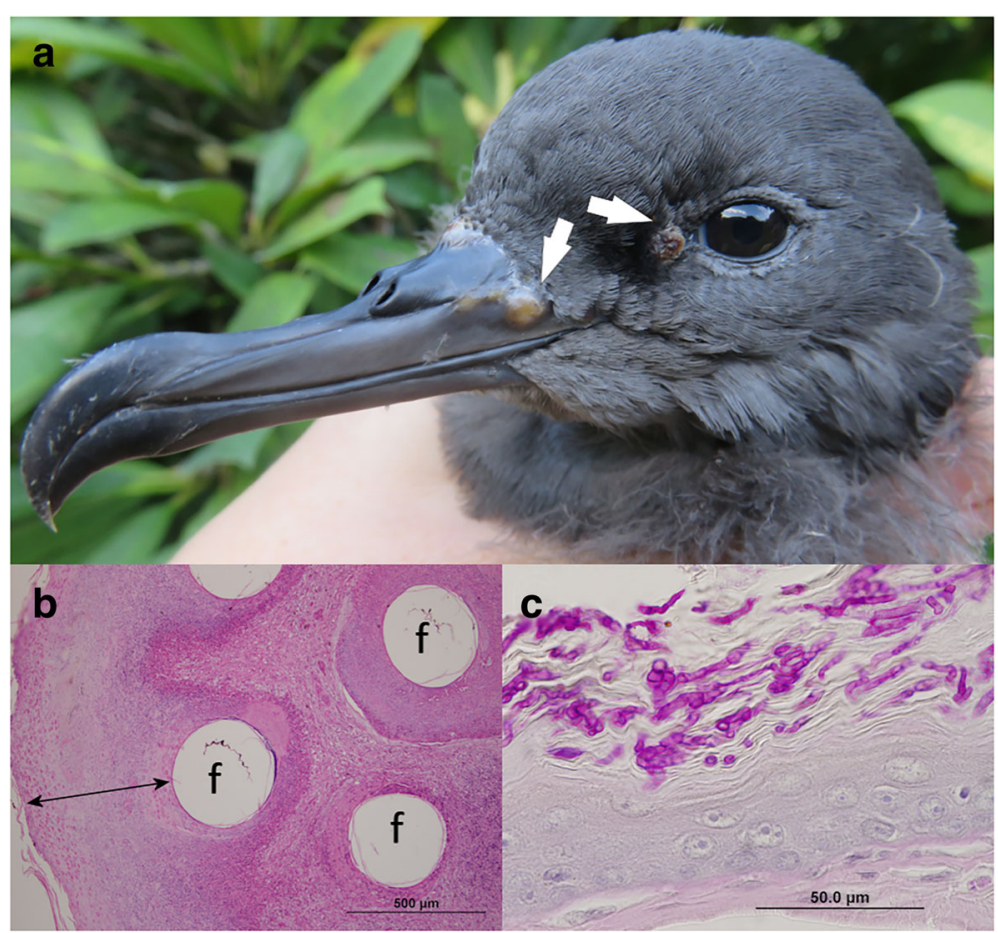

Fig. 1 Pathological evidence of characteristic pox and fungal lesions. a Grossly well circumscribed, popular, crusting pox lesions across the featherless skins (white arrows). b Feather skin demonstrating diffuse proliferation of the epidermis and follicular infundibula with keratinocytes containing eosinophilic intracytoplasmic inclusions (Bollinger bodies) and serocellular surface crust (double head arrow). c Inflammatory exudates associated with serocellular surface crust that contained abundant branching fungal hyphae and aggregations of bacteria

\section{Genome sequence and annotation of viruses}

The Shearwaterpox virus complete genomes were assembled using CLC Genomics workbench 9.5.2 under La Trobe University Genomics Platform. The assembled complete genomes of SWPV-1 and -2 were 326,929 and $351,108 \mathrm{nt}$, respectively. The SWPV-1 and -2 complete genomes were annotated as described in the methods using CNPV as a reference genome (Additional file 1: Table S1 and Additional file 2: Table S2). We took a conservative approach to the annotation in order to minimize the inclusion of ORFs that were unlikely to represent functional genes. Table 1 lists the 310 and 312 genes annotated for SWPV-1 and -2 , respectively. For the most part, these two new complete genomes are collinear to CNPV although there are a number of rearrangements of blocks of 1-6 genes in addition to insertions and deletions with respect to CNPV (Table 1). Comparison of the predicted proteins of SWPV-2 to orthologs in CNPV reveal the vast majority are $>98 \%$ identical (aa), with more than 80 being completely conserved. In contrast, the orthologs of SWPV-1 only have an average aa identity of $67 \%$ to CNPV. However, with the lower average identity, greater genetic distance, comes a much greater range of variation in the level of identity and a significant number of predicted proteins are $80-90 \%$ identical (aa) to CNPV orthologs.
This difference in similarity between the new viruses and CNPV is easily visualized in complete genome dotplots (Fig. 2a and b). Significantly more indels are present in the SWPV-1 vs CNPV dotplot (Fig. 2a). However, when the phylogenetic relationships of these viruses were examined together with the other available complete genomes, SWPV-1 was still part of the CNPV clade (Fig. 3a). From this alignment, CNPV is $99.2 \%$, $78.7 \%, 69.4 \%, 69.5 \%, 68.8 \%$ and $66.5 \%$ identical (nt) to SWPV-2, SWPV-1, FeP2, PEPV, FWPV and TKPV, respectively. A greater selection of viruses was included in the phylogenetic tree by using other fragments of incompletely sequenced avipoxvirus genomes. For example, Vultur gryphus poxvirus (VGPV), Flamingopox virus (FGPV) and Hawaiian goose poxvirus (HGPV) are all more similar to SWPV-2 and CNPV than SWPV-1 (Fig. 3b), this confirms that other poxviruses are as closely related to CNPV as SWPV-2. By also building phylogenetic trees with partial nucleotide sequences from the p4b gene (Fig. 4) and DNA polymerase gene (Fig. 5), we discovered that several other viruses are within the SWPV-1, SWPV-2 and CNPV clade. This includes a poxvirus isolated from Houbara Bustards (Chlamydotis undulata) in captive-breeding programs in Morocco [23], but named CNPV-morocco, and avipoxviruses isolated from American crow (Corvus 
Table 1 Shearwaterpox virus (SWPV) genome annotations and comparative analysis of ORFs relative to CNPV genomes

\begin{tabular}{|c|c|c|c|c|c|c|c|c|c|}
\hline $\begin{array}{l}\text { SWPV1 } \\
\text { synteny }\end{array}$ & $\begin{array}{l}\text { SWPV2 } \\
\text { synteny }\end{array}$ & $\begin{array}{l}\text { CNPV } \\
\text { synteny }\end{array}$ & CNPV BLAST hits & $\begin{array}{l}\text { SWPV1 \% } \\
\text { identity }\end{array}$ & $\begin{array}{l}\text { SWPV2 \% } \\
\text { identity }\end{array}$ & $\begin{array}{l}\text { SWPV1 AA } \\
\text { size }\end{array}$ & $\begin{array}{l}\text { SWPV2 AA } \\
\text { size }\end{array}$ & $\begin{array}{l}\text { Reference AA } \\
\text { size }\end{array}$ & notes \\
\hline & & CNPV001 & $\begin{array}{l}\text { CNPV001 } \\
\text { hypothetical protein }\end{array}$ & & & & & 72 & \\
\hline & SWPV2-001 & CNPV002 & $\begin{array}{l}\text { CNPV002 } \\
\text { hypothetical protein }\end{array}$ & & 92.941 & & 171 & 171 & \\
\hline SWPV1-001 & SWPV2-002 & CNPV003 & $\begin{array}{l}\text { CNPV003 C-type } \\
\text { lectin-like protein }\end{array}$ & 32.044 & 85.99 & 181 & 208 & 204 & \\
\hline SWPV1-002 & & CNPV004 & $\begin{array}{l}\text { CNPV004 ankyrin } \\
\text { repeat protein }\end{array}$ & 56.458 & & 468 & & 514 & \\
\hline \multirow[t]{3}{*}{ SWPV1-003 } & SWPV2-003 & CNPV005 & $\begin{array}{l}\text { CNPV005 conserved } \\
\text { hypothetical protein }\end{array}$ & 87.387 & 99.55 & 220 & 222 & 222 & \\
\hline & SWPV2-004 & CNPV006 & $\begin{array}{l}\text { CNPV006 } \\
\text { hypothetical protein }\end{array}$ & & 88.71 & & 134 & 182 & $\begin{array}{l}\text { SWPV2: C-terminus } \\
\text { fragment, not likely } \\
\text { translated }\end{array}$ \\
\hline & & CNPV007 & $\begin{array}{l}\text { CNPV007 ankyrin } \\
\text { repeat protein }\end{array}$ & & & & & 674 & \\
\hline \multirow[t]{8}{*}{ SWPV1-004 } & SWPV2-005 & CNPV008 & $\begin{array}{l}\text { CNPV008 C-type } \\
\text { lectin-like protein }\end{array}$ & 50 & 98.225 & 174 & 169 & 169 & \\
\hline & SWPV2-006 & CNPV009 & $\begin{array}{l}\text { CNPV009 ankyrin } \\
\text { repeat protein }\end{array}$ & & 99.564 & & 688 & 688 & \\
\hline & & CNPV010 & $\begin{array}{l}\text { CNPV010 ankyrin } \\
\text { repeat protein }\end{array}$ & & & & & 734 & \\
\hline & SWPV2-007 & CNPV011 & $\begin{array}{l}\text { CNPV011 ankyrin } \\
\text { repeat protein }\end{array}$ & & 99.147 & & 586 & 586 & \\
\hline & SWPV2-008 & CNPV012 & $\begin{array}{l}\text { CNPV012 } \\
\text { hypothetical protein }\end{array}$ & & 100 & & 189 & 189 & \\
\hline & SWPV2-009 & CNPV013 & $\begin{array}{l}\text { CNPV013 } \\
\text { hypothetical protein }\end{array}$ & & 98.81 & & 168 & 168 & \\
\hline & SWPV2-010 & CNPV014 & $\begin{array}{l}\text { CNPV014 } \\
\text { immunoglobulin-like } \\
\text { domain protein }\end{array}$ & & 99.184 & & 490 & 490 & \\
\hline & SWPV2-011 & CNPV015 & $\begin{array}{l}\text { CNPV015 ankyrin } \\
\text { repeat protein }\end{array}$ & & 97.538 & & 528 & 528 & \\
\hline SWPV1-005 & & & $\begin{array}{l}\text { CNPV035 C-type } \\
\text { lectin-like protein }\end{array}$ & 35.556 & & 138 & & 134 & \\
\hline SWPV1-006 & & & $\begin{array}{l}\text { CNPV318 ankyrin } \\
\text { repeat protein }\end{array}$ & 58.932 & & 487 & & 514 & \\
\hline SWPV1-007 & SWPV2-012 & CNPV016 & $\begin{array}{l}\text { CNPV016 C-type } \\
\text { lectin-like protein }\end{array}$ & 52.128 & 98.81 & 117 & 168 & 168 & \\
\hline SWPV1-008 & SWPV2-013 & CNPV017 & $\begin{array}{l}\text { CNPV017 ankyrin } \\
\text { repeat protein }\end{array}$ & 64.471 & 97.912 & 425 & 479 & 486 & \\
\hline \multirow[t]{3}{*}{ SWPV1-009 } & & & $\begin{array}{l}\text { CNPV295 ankyrin } \\
\text { repeat protein }\end{array}$ & 56.41 & & 277 & & 396 & \\
\hline & SWPV2-014 & CNPV018 & $\begin{array}{l}\text { CNPV018 IL-10-like } \\
\text { protein }\end{array}$ & & 90.805 & & 190 & 191 & \\
\hline & SWPV2-015 & CNPV019 & $\begin{array}{l}\text { CNPV019 ankyrin } \\
\text { repeat protein }\end{array}$ & & 99.083 & & 436 & 436 & \\
\hline SWPV1-010 & SWPV2-016 & CNPV020 & $\begin{array}{l}\text { CNPV020 ankyrin } \\
\text { repeat protein }\end{array}$ & 56.311 & 99.761 & 412 & 419 & 419 & \\
\hline SWPV1-011 & & & $\begin{array}{l}\text { CNPV320 lg-like do } \\
\text { main protein }\end{array}$ & 31.656 & & 483 & & 469 & \\
\hline SWPV1-012 & SWPV2-017 & CNPV021 & $\begin{array}{l}\text { CNPV021 ankyrin } \\
\text { repeat protein }\end{array}$ & 62.313 & 99.626 & 528 & 535 & 535 & \\
\hline SWPV1-013 & SWPV2-018 & CNPV022 & $\begin{array}{l}\text { CNPV022 putative } \\
\text { serpin }\end{array}$ & 65.642 & 98.324 & 356 & 358 & 358 & \\
\hline
\end{tabular}


Table 1 Shearwaterpox virus (SWPV) genome annotations and comparative analysis of ORFs relative to CNPV genomes (Continued)

\begin{tabular}{|c|c|c|c|c|c|c|c|c|c|}
\hline SWPV1-014 & & & $\begin{array}{l}\text { PEPV260 ankyrin } \\
\text { repeat protein }\end{array}$ & 53.158 & & 190 & & 192 & \\
\hline \multirow[t]{3}{*}{ SWPV1-015 } & & & $\begin{array}{l}\text { CNPV011 ankyrin } \\
\text { repeat protein }\end{array}$ & 34 & & 530 & & 586 & \\
\hline & SWPV2-019 & CNPV023 & $\begin{array}{l}\text { CNPV023 vaccinia } \\
\text { C4L/C10L-like protein }\end{array}$ & & 98.595 & & 424 & 427 & \\
\hline & SWPV2-020 & CNPV024 & $\begin{array}{l}\text { CNPV024 } \\
\text { hypothetical protein }\end{array}$ & & 96.629 & & 178 & 178 & \\
\hline SWPV1-016 & SWPV2-021 & CNPV025 & $\begin{array}{l}\text { CNPV025 alpha- } \\
\text { SNAP-like protein }\end{array}$ & 57.491 & 98.667 & 304 & 300 & 300 & \\
\hline SWPV1-017 & SWPV2-022 & CNPV026 & $\begin{array}{l}\text { CNPV026 ankyrin } \\
\text { repeat protein }\end{array}$ & 54.271 & 98.953 & 397 & 382 & 382 & \\
\hline SWPV1-018 & SWPV2-023 & CNPV027 & $\begin{array}{l}\text { CNPV027 ankyrin } \\
\text { repeat protein }\end{array}$ & 59.375 & 98.722 & 646 & 626 & 626 & \\
\hline SWPV1-019 & SWPV2-024 & CNPV028 & $\begin{array}{l}\text { CNPV028 ankyrin } \\
\text { repeat protein }\end{array}$ & 57.618 & 99.164 & 408 & 365 & 362 & \\
\hline SWPV1-020 & SWPV2-025 & CNPV029 & $\begin{array}{l}\text { CNPV029 C-type } \\
\text { lectin-like protein }\end{array}$ & 50.35 & 99.296 & 142 & 142 & 142 & \\
\hline SWPV1-021 & SWPV2-026 & CNPV030 & $\begin{array}{l}\text { CNPV030 ankyrin } \\
\text { repeat protein }\end{array}$ & 63.72 & 98.529 & 345 & 340 & 340 & \\
\hline SWPV1-022 & SWPV2-027 & CNPV031 & $\begin{array}{l}\text { CNPV031 } \\
\text { hypothetical protein }\end{array}$ & 60.331 & 97.479 & 120 & 119 & 119 & \\
\hline SWPV1-023 & & & $\begin{array}{l}\text { CNPV013 conserved } \\
\text { hypothetical protein }\end{array}$ & 44.048 & & 168 & & 168 & \\
\hline SWPV1-024 & SWPV2-028 & CNPV032 & $\begin{array}{l}\text { CNPV032 lg-like } \\
\text { domain putative IFN- } \\
\text { gamma binding } \\
\text { protein }\end{array}$ & 51.837 & 92.149 & 242 & 242 & 242 & \\
\hline \multirow[t]{3}{*}{ SWPV1-025 } & SWPV2-029 & CNPV033 & $\begin{array}{l}\text { CNPV033 Ig-like } \\
\text { domain protein }\end{array}$ & 48.095 & 93.496 & 238 & 246 & 246 & \\
\hline & SWPV2-030 & CNPV034 & $\begin{array}{l}\text { CNPV034 ankyrin } \\
\text { repeat protein }\end{array}$ & & 99.848 & & 659 & 659 & \\
\hline & SWPV2-031 & CNPV035 & $\begin{array}{l}\text { CNPV035 C-type } \\
\text { lectin-like protein }\end{array}$ & & 94.776 & & 133 & 134 & \\
\hline SWPV1-026 & SWPV2-032 & CNPV036 & $\begin{array}{l}\text { CNPV036 conserved } \\
\text { hypothetical protein }\end{array}$ & 48.235 & 98.947 & 88 & 95 & 95 & \\
\hline SWPV1-027 & SWPV2-033 & CNPV037 & $\begin{array}{l}\text { CNPV037 conserved } \\
\text { hypothetical protein }\end{array}$ & 63.068 & 99.441 & 178 & 179 & 179 & \\
\hline SWPV1-028 & SWPV2-034 & CNPV038 & $\begin{array}{l}\text { CNPV038 vaccinia } \\
\text { C4L/C10L-like protein }\end{array}$ & 54.523 & 99.516 & 411 & 413 & 413 & \\
\hline SWPV1-029 & SWPV2-035 & CNPV039 & $\begin{array}{l}\text { CNPV039 G protein- } \\
\text { coupled receptor-like } \\
\text { protein }\end{array}$ & 67.284 & 97.859 & 323 & 327 & 327 & \\
\hline SWPV1-030 & SWPV2-036 & CNPV040 & $\begin{array}{l}\text { CNPV040 ankyrin } \\
\text { repeat protein }\end{array}$ & 57.36 & 93.401 & 589 & 591 & 591 & $\begin{array}{l}\text { SWPV2: High SNP } \\
\text { Density }\end{array}$ \\
\hline SWPV1-031 & SWPV2-037 & CNPV041 & $\begin{array}{l}\text { CNPV041 ankyrin } \\
\text { repeat protein }\end{array}$ & 66.284 & 98.605 & 432 & 430 & 430 & \\
\hline SWPV1-032 & SWPV2-038 & CNPV042 & $\begin{array}{l}\text { CNPV042 ankyrin } \\
\text { repeat protein }\end{array}$ & 72.712 & 99.339 & 608 & 605 & 605 & \\
\hline SWPV1-033 & SWPV2-039 & CNPV043 & $\begin{array}{l}\text { CNPV043 conserved } \\
\text { hypothetical protein }\end{array}$ & 74.627 & 99.005 & 202 & 201 & 201 & \\
\hline SWPV1-034 & SWPV2-040 & CNPV044 & $\begin{array}{l}\text { CNPV044 ankyrin } \\
\text { repeat protein }\end{array}$ & 67.316 & 99.583 & 470 & 480 & 480 & \\
\hline
\end{tabular}


Table 1 Shearwaterpox virus (SWPV) genome annotations and comparative analysis of ORFs relative to CNPV genomes (Continued)

\begin{tabular}{|c|c|c|c|c|c|c|c|c|c|}
\hline SWPV1-035 & SWPV2-041 & CNPV045 & $\begin{array}{l}\text { CNPV045 G protein- } \\
\text { coupled receptor-like } \\
\text { protein }\end{array}$ & 65.231 & 100 & 331 & 332 & 332 & \\
\hline SWPV1-036 & SWPV2-042 & CNPV046 & $\begin{array}{l}\text { CNPV046 ankyrin } \\
\text { repeat protein }\end{array}$ & 68.08 & 98.667 & 452 & 450 & 450 & \\
\hline SWPV1-037 & SWPV2-043 & CNPV047 & $\begin{array}{l}\text { CNPV047 conserved } \\
\text { hypothetical protein }\end{array}$ & 65.6 & 99.194 & 125 & 124 & 124 & \\
\hline SWPV1-038 & SWPV2-044 & CNPV048 & $\begin{array}{l}\text { CNPV048 alkaline } \\
\text { phosphodiesterase- } \\
\text { like protein }\end{array}$ & 68.238 & 98.502 & 804 & 801 & 801 & \\
\hline SWPV1-039 & SWPV2-045 & CNPV049 & $\begin{array}{l}\text { CNPV049 } \\
\text { hypothetical protein }\end{array}$ & 72.667 & 100 & 148 & 150 & 150 & \\
\hline SWPV1-040 & SWPV2-046 & CNPV050 & $\begin{array}{l}\text { CNPV050 ankyrin } \\
\text { repeat protein }\end{array}$ & 67.422 & 98.864 & 352 & 352 & 352 & \\
\hline SWPV1-041 & SWPV2-047 & CNPV051 & $\begin{array}{l}\text { CNPV051 DNase II- } \\
\text { like protein }\end{array}$ & 63.683 & 96.75 & 398 & 408 & 401 & \\
\hline SWPV1-042 & SWPV2-048 & CNPV052 & $\begin{array}{l}\text { CNPV052 C-type } \\
\text { lectin-like protein }\end{array}$ & 50 & 100 & 182 & 171 & 171 & \\
\hline SWPV1-043 & & & $\begin{array}{l}\text { FWPV ankyrin repeat } \\
\text { protein }\end{array}$ & 45 & & 329 & & 406 & \\
\hline SWPV1-044 & SWPV2-049 & CNPV053 & $\begin{array}{l}\text { CNPV053 conserved } \\
\text { hypothetical protein }\end{array}$ & 68.148 & 100 & 135 & 146 & 146 & \\
\hline SWPV1-045 & SWPV2-050 & CNPV054 & $\begin{array}{l}\text { CNPV054 conserved } \\
\text { hypothetical protein }\end{array}$ & 62.59 & 99.286 & 141 & 140 & 140 & \\
\hline SWPV1-046 & SWPV2-051 & CNPV055 & $\begin{array}{l}\text { CNPV055 conserved } \\
\text { hypothetical protein }\end{array}$ & 74.534 & 100 & 162 & 163 & 163 & \\
\hline SWPV1-047 & SWPV2-052 & CNPV056 & CNPV056 dUTPase & 80.986 & 98.621 & 155 & 145 & 145 & \\
\hline SWPV1-048 & SWPV2-053 & CNPV057 & $\begin{array}{l}\text { CNPV057 putative } \\
\text { serpin }\end{array}$ & 63.107 & 99.02 & 301 & 306 & 306 & \\
\hline SWPV1-049 & SWPV2-054 & CNPV058 & $\begin{array}{l}\text { CNPV058 bcl-2 like } \\
\text { protein }\end{array}$ & 51.744 & 98.857 & 174 & 180 & 175 & \\
\hline SWPV1-050 & SWPV2-055 & CNPV059 & $\begin{array}{l}\text { CNPV059 putative } \\
\text { serpin }\end{array}$ & 71.302 & 99.704 & 338 & 338 & 338 & \\
\hline SWPV1-051 & SWPV2-056 & CNPV060 & $\begin{array}{l}\text { CNPV060 conserved } \\
\text { hypothetical protein }\end{array}$ & 46.939 & 95.098 & 236 & 206 & 316 & $\begin{array}{l}\text { SWPV2: Large internal } \\
\text { deletion, Translated } \\
\text { but not likely } \\
\text { functional }\end{array}$ \\
\hline SWPV1-052 & SWPV2-057 & CNPV061 & CNPV061 DNA ligase & 80.995 & 98.761 & 567 & 565 & 565 & \\
\hline SWPV1-053 & SWPV2-058 & CNPV062 & $\begin{array}{l}\text { CNPV062 putative } \\
\text { serpin }\end{array}$ & 70.94 & 100 & 349 & 350 & 350 & \\
\hline SWPV1-054 & SWPV2-059 & CNPV063 & $\begin{array}{l}\text { CNPV063 } \\
\text { hydroxysteroid } \\
\text { dehydrogenase-like } \\
\text { protein }\end{array}$ & 71.348 & 99.441 & 359 & 358 & 358 & \\
\hline SWPV1-055 & SWPV2-060 & CNPV064 & $\begin{array}{l}\text { CNPV064 TGF-beta- } \\
\text { like protein }\end{array}$ & 56.897 & 98.587 & 272 & 283 & 282 & \\
\hline SWPV1-056 & SWPV2-061 & CNPV065 & $\begin{array}{l}\text { CNPV065 } \\
\text { semaphorin-like } \\
\text { protein }\end{array}$ & 69.735 & 99.485 & 573 & 583 & 583 & \\
\hline \multirow[t]{2}{*}{ SWPV1-057 } & SWPV2-062 & CNPV066 & $\begin{array}{l}\text { CNPV066 } \\
\text { hypothetical protein }\end{array}$ & 37.349 & 98.519 & 139 & 399 & 405 & \multirow[t]{3}{*}{$\begin{array}{l}\text { SWPV1: Low BLAST } \\
\text { hits, } \\
\text { possible unique ORF }\end{array}$} \\
\hline & SWPV2-063 & CNPV067 & $\begin{array}{l}\text { CNPV067 } \\
\text { hypothetical protein }\end{array}$ & & 100 & & 57 & 57 & \\
\hline SWPV1-058 & & & no significant BLAST & & & & & 239 & \\
\hline
\end{tabular}


Table 1 Shearwaterpox virus (SWPV) genome annotations and comparative analysis of ORFs relative to CNPV genomes (Continued)

\begin{tabular}{|c|c|c|c|c|c|c|c|c|c|}
\hline & & & & & & & & & $\begin{array}{l}\text { SWPV1: Possible } \\
\text { Unique } \\
\text { ORF }\end{array}$ \\
\hline SWPV1-059 & SWPV2-064 & CNPV068 & $\begin{array}{l}\text { CNPV068 GNS1/ } \\
\text { SUR4-like protein }\end{array}$ & 84.825 & 99.611 & 257 & 257 & 257 & \\
\hline SWPV1-060 & SWPV2-065 & CNPV069 & $\begin{array}{l}\text { CNPV069 late } \\
\text { transcription factor } \\
\text { VLTF-2 }\end{array}$ & 87.5 & 100 & 154 & 155 & 155 & \\
\hline SWPV1-061 & SWPV2-066 & CNPV070 & $\begin{array}{l}\text { CNPV070 putative } \\
\text { rifampicin resistance } \\
\text { protein, IMV } \\
\text { assembly }\end{array}$ & 88.065 & 100 & 553 & 551 & 551 & \\
\hline \multirow[t]{2}{*}{ SWPV1-062 } & SWPV2-067 & CNPV071 & $\begin{array}{l}\text { CNPV071 mRNA } \\
\text { capping enzyme } \\
\text { small subunit }\end{array}$ & 89.273 & 100 & 289 & 289 & 289 & \\
\hline & SWPV2-068 & CNPV072 & $\begin{array}{l}\text { CNPV072 CC } \\
\text { chemokine-like } \\
\text { protein }\end{array}$ & & 96.262 & & 132 & 312 & $\begin{array}{l}\text { SWPV2: N-terminus } \\
\text { fragment }\end{array}$ \\
\hline SWPV1-063 & SWPV2-069 & CNPV073 & $\begin{array}{l}\text { CNPV073 } \\
\text { hypothetical protein }\end{array}$ & 45.263 & 100 & 110 & 109 & 109 & \\
\hline SWPV1-064 & SWPV2-070 & CNPV074 & $\begin{array}{l}\text { CNPV074 NPH-I, tran- } \\
\text { scription termination } \\
\text { factor }\end{array}$ & 92.756 & 99.685 & 635 & 635 & 635 & \\
\hline SWPV1-065 & SWPV2-071 & CNPV075 & $\begin{array}{l}\text { CNPV075 mutT motif } \\
\text { putative gene } \\
\text { expression regulator }\end{array}$ & 79.295 & 100 & 226 & 228 & 230 & \\
\hline \multirow[t]{2}{*}{ SWPV1-066 } & SWPV2-072 & CNPV076 & CNPV076 mutT motif & 84.549 & 99.569 & 233 & 232 & 232 & \\
\hline & & CNPV077 & $\begin{array}{l}\text { CNPV077 } \\
\text { hypothetical protein }\end{array}$ & & & & & 78 & \\
\hline SWPV1-067 & & & $\begin{array}{l}\text { CNPV011 ankyrin } \\
\text { repeat protein }\end{array}$ & 29.806 & & 435 & & 586 & \\
\hline \multirow[t]{2}{*}{ SWPV1-068 } & SWPV2-073 & CNPV078 & $\begin{array}{l}\text { CNPV078 RNA } \\
\text { polymerase subunit } \\
\text { RPO18 }\end{array}$ & 82.39 & 100 & 161 & 160 & 160 & \\
\hline & SWPV2-074 & CNPV079 & $\begin{array}{l}\text { CNPV079 lg-like do- } \\
\text { main protein }\end{array}$ & & 94.161 & & 274 & 272 & \\
\hline \multirow[t]{2}{*}{ SWPV1-069 } & SWPV2-075 & CNPV080 & $\begin{array}{l}\text { CNPV080 early } \\
\text { transcription factor } \\
\text { small subunit VETFS }\end{array}$ & 96.682 & 100 & 633 & 633 & 633 & \\
\hline & SWPV2-076 & CNPV081 & $\begin{array}{l}\text { CNPV081 lg-like do- } \\
\text { main protein }\end{array}$ & & 97.006 & & 334 & 333 & \\
\hline SWPV1-070 & SWPV2-077 & CNPV082 & $\begin{array}{l}\text { CNPV082 NTPase, } \\
\text { DNA replication }\end{array}$ & 88.818 & 99.748 & 790 & 794 & 794 & \\
\hline SWPV1-071 & SWPV2-078 & CNPV083 & $\begin{array}{l}\text { CNPV083 CC } \\
\text { chemokine-like } \\
\text { protein }\end{array}$ & 60.352 & 91.855 & 223 & 221 & 221 & \\
\hline SWPV1-072 & & & $\begin{array}{l}\text { CNPV215 CC } \\
\text { chemokine-like } \\
\text { protein }\end{array}$ & 30.994 & & 195 & & 204 & \\
\hline SWPV1-073 & SWPV2-079 & CNPV084 & $\begin{array}{l}\text { CNPV084 uracil DNA } \\
\text { glycosylase }\end{array}$ & 86.364 & 97.706 & 220 & 218 & 218 & \\
\hline SWPV1-074 & SWPV2-080 & CNPV085 & $\begin{array}{l}\text { CNPV085 putative } \\
\text { RNA phosphatase }\end{array}$ & 67.895 & 74.312 & 245 & 303 & 403 & $\begin{array}{l}\text { SWPV2: High SNP } \\
\text { Density }\end{array}$ \\
\hline SWPV1-075 & & & $\begin{array}{l}\text { CNPV216 conserved } \\
\text { hypothetical protein }\end{array}$ & 39.225 & & 398 & & 404 & \\
\hline
\end{tabular}


Table 1 Shearwaterpox virus (SWPV) genome annotations and comparative analysis of ORFs relative to CNPV genomes (Continued)

\begin{tabular}{|c|c|c|c|c|c|c|c|c|c|}
\hline \multirow[t]{2}{*}{ SWPV1-076 } & SWPV2-081 & CNPV086 & $\begin{array}{l}\text { CNPV086 TNFR-like } \\
\text { protein }\end{array}$ & 67.327 & 71.569 & 103 & 112 & 117 & \\
\hline & SWPV2-082 & CNPV087 & $\begin{array}{l}\text { CNPV087 putative } \\
\text { glutathione } \\
\text { peroxidase }\end{array}$ & & 98.473 & & 131 & 198 & $\begin{array}{l}\text { SWPV2: C-terminus } \\
\text { fragment, not likely } \\
\text { translated }\end{array}$ \\
\hline SWPV1-077 & & & $\begin{array}{l}\text { CNPV227 N1R/p28- } \\
\text { like protein }\end{array}$ & 74.638 & & 256 & & 359 & \\
\hline SWPV1-078 & SWPV2-083 & CNPV088 & $\begin{array}{l}\text { CNPV088 conserved } \\
\text { hypothetical protein }\end{array}$ & 55.769 & 97 & 104 & 100 & 100 & \\
\hline SWPV1-079 & SWPV2-084 & CNPV089 & $\begin{array}{l}\text { CNPV089 conserved } \\
\text { hypothetical protein }\end{array}$ & 64.935 & 100 & 164 & 159 & 159 & \\
\hline SWPV1-080 & SWPV2-085 & CNPV090 & $\begin{array}{l}\text { CNPV090 conserved } \\
\text { hypothetical protein }\end{array}$ & 62.393 & 100 & 124 & 127 & 127 & \\
\hline SWPV1-081 & SWPV2-086 & CNPV091 & $\begin{array}{l}\text { CNPV091 HT motif } \\
\text { protein }\end{array}$ & 64.634 & 100 & 77 & 83 & 83 & \\
\hline SWPV1-082 & SWPV2-087 & CNPV092 & $\begin{array}{l}\text { CNPV092 conserved } \\
\text { hypothetical protein }\end{array}$ & 64.901 & 97.945 & 140 & 146 & 146 & \\
\hline SWPV1-083 & SWPV2-088 & CNPV093 & $\begin{array}{l}\text { CNPV093 virion } \\
\text { protein }\end{array}$ & 60.37 & 99.625 & 270 & 267 & 267 & \\
\hline SWPV1-084 & SWPV2-089 & CNPV094 & $\begin{array}{l}\text { CNPV094 T10-like } \\
\text { protein }\end{array}$ & 75 & 98.909 & 282 & 275 & 275 & \\
\hline SWPV1-085 & SWPV2-090 & CNPV095 & $\begin{array}{l}\text { CNPV095 conserved } \\
\text { hypothetical protein }\end{array}$ & 71.111 & 100 & 47 & 45 & 45 & \\
\hline SWPV1-086 & SWPV2-091 & CNPV096 & CNPV096 ubiquitin & 100 & 100 & 77 & 85 & 85 & \\
\hline SWPV1-087 & SWPV2-092 & CNPV097 & $\begin{array}{l}\text { CNPV097 conserved } \\
\text { hypothetical protein }\end{array}$ & 70.031 & 99.705 & 298 & 339 & 339 & \\
\hline SWPV1-088 & SWPV2-093 & CNPV098 & $\begin{array}{l}\text { CNPV098 } \\
\text { hypothetical protein }\end{array}$ & 67.442 & 98.75 & 61 & 80 & 80 & \\
\hline SWPV1-089 & SWPV2-094 & CNPV099 & $\begin{array}{l}\text { CNPV099 beta-NGF- } \\
\text { like protein }\end{array}$ & 62.162 & 97.949 & 186 & 195 & 195 & \\
\hline \multirow[t]{2}{*}{ SWPV1-090 } & SWPV2-095 & CNPV100 & $\begin{array}{l}\text { CNPV100 putative } \\
\text { interleukin binding } \\
\text { protein }\end{array}$ & 51.176 & 98.225 & 211 & 168 & 169 & \\
\hline & SWPV2-096 & CNPV101 & $\begin{array}{l}\text { CNPV101 } \\
\text { hypothetical protein }\end{array}$ & & 98.824 & & 85 & 85 & \\
\hline SWPV1-091 & SWPV2-097 & CNPV102 & $\begin{array}{l}\text { CNPV102 conserved } \\
\text { hypothetical protein }\end{array}$ & 54.167 & 99.048 & 102 & 105 & 105 & \\
\hline SWPV1-092 & SWPV2-098 & CNPV103 & $\begin{array}{l}\text { CNPV103 N1R/p28- } \\
\text { like protein }\end{array}$ & 62.304 & 98.947 & 188 & 190 & 190 & \\
\hline SWPV1-093 & SWPV2-099 & CNPV104 & $\begin{array}{l}\text { CNPV104 putative } \\
\text { glutaredoxin 2, virion } \\
\text { morphogenesis }\end{array}$ & 86.4 & 99.2 & 125 & 125 & 125 & \\
\hline SWPV1-094 & SWPV2-100 & CNPV105 & $\begin{array}{l}\text { CNPV105 conserved } \\
\text { hypothetical protein }\end{array}$ & 77.35 & 98.718 & 234 & 234 & 234 & \\
\hline \multirow[t]{2}{*}{ SWPV1-095 } & SWPV2-101 & CNPV106 & $\begin{array}{l}\text { CNPV106 putative } \\
\text { elongation factor }\end{array}$ & 76.829 & 98.039 & 103 & 102 & 102 & \\
\hline & SWPV2-102 & CNPV107 & $\begin{array}{l}\text { CNPV107 } \\
\text { hypothetical protein }\end{array}$ & & 100 & & 77 & 77 & \\
\hline SWPV1-096 & & & $\begin{array}{l}\text { PEPV083 } \\
\text { transforming growth } \\
\text { factor B }\end{array}$ & 64 & & 444 & & 336 & \\
\hline SWPV1-097 & SWPV2-103 & CNPV108 & $\begin{array}{l}\text { CNPV108 putative } \\
\text { metalloprotease, } \\
\text { virion morphogenesis }\end{array}$ & 85.489 & 100 & 633 & 632 & 632 & \\
\hline SWPV1-098 & SWPV2-104 & CNPV109 & $\begin{array}{l}\text { CNPV109 NPH-II, RNA } \\
\text { helicase }\end{array}$ & 86.05 & 99.706 & 681 & 681 & 681 & \\
\hline
\end{tabular}


Table 1 Shearwaterpox virus (SWPV) genome annotations and comparative analysis of ORFs relative to CNPV genomes (Continued)

\begin{tabular}{|c|c|c|c|c|c|c|c|c|c|}
\hline SWPV1-099 & SWPV2-105 & CNPV110 & $\begin{array}{l}\text { CNPV110 virion core } \\
\text { proteinase }\end{array}$ & 87.441 & 99.763 & 421 & 422 & 422 & \\
\hline SWPV1-100 & SWPV2-106 & CNPV111 & $\begin{array}{l}\text { CNPV111 DNA- } \\
\text { binding protein }\end{array}$ & 80.612 & 99.488 & 391 & 391 & 391 & \\
\hline SWPV1-101 & SWPV2-107 & CNPV112 & $\begin{array}{l}\text { CNPV112 putative } \\
\text { IMV membrane } \\
\text { protein }\end{array}$ & 81.481 & 100 & 81 & 81 & 81 & \\
\hline SWPV1-102 & SWPV2-108 & CNPV113 & $\begin{array}{l}\text { CNPV113 thymidine } \\
\text { kinase }\end{array}$ & 75.978 & 99.441 & 181 & 179 & 179 & \\
\hline SWPV1-103 & SWPV2-109 & CNPV114 & $\begin{array}{l}\text { CNPV1 } 14 \text { HT motif } \\
\text { protein }\end{array}$ & 69.62 & 100 & 79 & 82 & 82 & \\
\hline SWPV1-104 & SWPV2-110 & CNPV115 & $\begin{array}{l}\text { CNPV115 DNA- } \\
\text { binding } \\
\text { phosphoprotein }\end{array}$ & 71.429 & 82.353 & 282 & 289 & 289 & $\begin{array}{l}\text { SWPV2: High SNP } \\
\text { density }\end{array}$ \\
\hline SWPV1-105 & SWPV2-111 & CNPV116 & $\begin{array}{l}\text { CNPV116 unnamed } \\
\text { protein product }\end{array}$ & 73.913 & 98.551 & 66 & 69 & 69 & \\
\hline SWPV1-106 & SWPV2-112 & CNPV117 & $\begin{array}{l}\text { CNPV117 DNA- } \\
\text { binding virion } \\
\text { protein }\end{array}$ & 88.854 & 99.677 & 314 & 310 & 310 & \\
\hline SWPV1-107 & SWPV2-113 & CNPV118 & $\begin{array}{l}\text { CNPV118 conserved } \\
\text { hypothetical protein }\end{array}$ & 75.762 & 99.387 & 656 & 652 & 653 & \\
\hline SWPV1-108 & SWPV2-114 & CNPV119 & $\begin{array}{l}\text { CNPV119 virion core } \\
\text { protein }\end{array}$ & 83.969 & 100 & 131 & 131 & 131 & \\
\hline SWPV1-109 & SWPV2-115 & CNPV120 & $\begin{array}{l}\text { CNPV120 putative } \\
\text { IMV redox protein, } \\
\text { virus assembly }\end{array}$ & 80.851 & 100 & 94 & 93 & 93 & \\
\hline SWPV1-110 & SWPV2-116 & CNPV121 & $\begin{array}{l}\text { CNPV121 DNA } \\
\text { polymerase }\end{array}$ & 89.17 & 99.899 & 988 & 988 & 988 & \\
\hline SWPV1-111 & & CNPV122 & $\begin{array}{l}\text { CNPV122 putative } \\
\text { membrane protein }\end{array}$ & 83.088 & & 273 & & 274 & \\
\hline SWPV1-112 & SWPV2-117 & CNPV123 & $\begin{array}{l}\text { CNPV123 conserved } \\
\text { hypothetical protein }\end{array}$ & 82.312 & 85.336 & 571 & 502 & 571 & $\begin{array}{l}\text { SWPV2: High SNP } \\
\text { density }\end{array}$ \\
\hline SWPV1-113 & SWPV2-118 & CNPV124 & $\begin{array}{l}\text { CNPV124 variola } \\
\text { B22R-like protein }\end{array}$ & 67 & 98.957 & 1906 & 1916 & 1918 & \\
\hline SWPV1-114 & SWPV2-119 & CNPV125 & $\begin{array}{l}\text { CNPV125 variola } \\
\text { B22R-like protein }\end{array}$ & 71.669 & 99.66 & 1742 & 1767 & 1767 & \\
\hline \multirow[t]{2}{*}{ SWPV1-115 } & SWPV2-120 & CNPV126 & $\begin{array}{l}\text { CNPV126 variola } \\
\text { B22R-like protein }\end{array}$ & 64.456 & 98.847 & 1902 & 1839 & 1951 & $\begin{array}{l}\text { SWPV2: N-terminus } \\
\text { fragment }\end{array}$ \\
\hline & SWPV2-121 & & $\begin{array}{l}\text { CNPV126 variola } \\
\text { B22R-like protein }\end{array}$ & & 96 & & 153 & 1951 & $\begin{array}{l}\text { SWPV2: C-terminus } \\
\text { fragment, not likely } \\
\text { translated }\end{array}$ \\
\hline SWPV1-116 & SWPV2-122 & CNPV127 & $\begin{array}{l}\text { CNPV127 RNA } \\
\text { polymerase subunit } \\
\text { RPO30 }\end{array}$ & 96.154 & 100 & 182 & 182 & 182 & \\
\hline SWPV1-117 & SWPV2-123 & CNPV128 & $\begin{array}{l}\text { CNPV128 conserved } \\
\text { hypothetical protein }\end{array}$ & 77.072 & 98.752 & 742 & 721 & 721 & $\begin{array}{l}\text { SWPV2: High SNP } \\
\text { Density }\end{array}$ \\
\hline SWPV1-118 & SWPV2-124 & CNPV129 & $\begin{array}{l}\text { CNPV129 poly(A) } \\
\text { polymerase large } \\
\text { subunit PAPL }\end{array}$ & 83.898 & 99.788 & 472 & 472 & 472 & \\
\hline SWPV1-119 & SWPV2-125 & CNPV130 & $\begin{array}{l}\text { CNPV130 DNA- } \\
\text { binding virion core } \\
\text { protein }\end{array}$ & 76.471 & 100 & 114 & 119 & 119 & \\
\hline SWPV1-120 & SWPV2-126 & CNPV131 & $\begin{array}{l}\text { CNPV131 conserved } \\
\text { hypothetical protein }\end{array}$ & 64.115 & 99.517 & 212 & 207 & 207 & \\
\hline SWPV1-121 & SWPV2-127 & CNPV132 & $\begin{array}{l}\text { CNPV132 conserved } \\
\text { hypothetical protein }\end{array}$ & 81.081 & 99.324 & 151 & 148 & 148 & \\
\hline
\end{tabular}


Table 1 Shearwaterpox virus (SWPV) genome annotations and comparative analysis of ORFs relative to CNPV genomes (Continued)

\begin{tabular}{|c|c|c|c|c|c|c|c|c|c|}
\hline SWPV1-122 & SWPV2-128 & CNPV133 & $\begin{array}{l}\text { CNPV133 conserved } \\
\text { hypothetical protein }\end{array}$ & 73.737 & 100 & 90 & 99 & 99 & \\
\hline SWPV1-123 & SWPV2-129 & CNPV134 & $\begin{array}{l}\text { CNPV134 variola } \\
\text { B22R-like protein }\end{array}$ & 65.517 & 99.001 & 1774 & 1801 & 1801 & \\
\hline SWPV1-124 & SWPV2-130 & CNPV135 & $\begin{array}{l}\text { CNPV135 putative } \\
\text { palmitylated EEV } \\
\text { envelope lipase }\end{array}$ & 89.418 & 99.735 & 378 & 378 & 378 & \\
\hline SWPV1-125 & SWPV2-131 & CNPV136 & $\begin{array}{l}\text { CNPV136 putative } \\
\text { EEV maturation } \\
\text { protein }\end{array}$ & 75.602 & 99.68 & 622 & 625 & 625 & \\
\hline SWPV1-126 & SWPV2-132 & CNPV137 & $\begin{array}{l}\text { CNPV137 conserved } \\
\text { hypothetical protein }\end{array}$ & 62.26 & 98.925 & 467 & 462 & 465 & \\
\hline SWPV1-127 & SWPV2-133 & CNPV138 & $\begin{array}{l}\text { CNPV138 putative } \\
\text { serine/threonine } \\
\text { protein kinase, virus } \\
\text { assembly }\end{array}$ & 83.632 & 100 & 445 & 444 & 444 & \\
\hline SWPV1-128 & SWPV2-134 & CNPV139 & $\begin{array}{l}\text { CNPV139 conserved } \\
\text { hypothetical protein }\end{array}$ & 81.69 & 100 & 213 & 213 & 213 & \\
\hline SWPV1-129 & SWPV2-135 & CNPV140 & $\begin{array}{l}\text { CNPV140 conserved } \\
\text { hypothetical protein }\end{array}$ & 78.788 & 100 & 65 & 66 & 66 & \\
\hline SWPV1-130 & SWPV2-136 & CNPV141 & $\begin{array}{l}\text { CNPV141 HAL3-like } \\
\text { domain protein }\end{array}$ & 88.333 & 100 & 182 & 184 & 184 & \\
\hline SWPV1-131 & & & $\begin{array}{l}\text { no significant BLAST } \\
\text { hits }\end{array}$ & 28 & & 101 & & 571 & $\begin{array}{l}\text { SWPV1: Possible } \\
\text { Unique } \\
\text { ORF }\end{array}$ \\
\hline SWPV1-132 & SWPV2-137 & CNPV142 & $\begin{array}{l}\text { CNPV142 N1R/p28- } \\
\text { like protein }\end{array}$ & 48.266 & 98.442 & 314 & 321 & 321 & \\
\hline SWPV1-133 & SWPV2-138 & CNPV143 & $\begin{array}{l}\text { CNPV143 ankyrin } \\
\text { repeat protein }\end{array}$ & 54.103 & 98.361 & 634 & 671 & 671 & \\
\hline SWPV1-134 & SWPV2-139 & CNPV144 & $\begin{array}{l}\text { CNPV144 ankyrin } \\
\text { repeat protein }\end{array}$ & 59.011 & 99.281 & 562 & 556 & 556 & \\
\hline SWPV1-135 & SWPV2-140 & CNPV145 & $\begin{array}{l}\text { CNPV145 conserved } \\
\text { hypothetical protein }\end{array}$ & 75.814 & 100 & 439 & 440 & 440 & \\
\hline SWPV1-136 & SWPV2-141 & CNPV146 & $\begin{array}{l}\text { CNPV146 RNA } \\
\text { polymerase subunit } \\
\text { RPO7 }\end{array}$ & 88.525 & 100 & 66 & 62 & 62 & \\
\hline SWPV1-137 & SWPV2-142 & CNPV147 & $\begin{array}{l}\text { CNPV147 conserved } \\
\text { hypothetical protein }\end{array}$ & 80.851 & 100 & 188 & 188 & 188 & \\
\hline \multirow[t]{6}{*}{ SWPV1-138 } & SWPV2-143 & CNPV148 & $\begin{array}{l}\text { CNPV148 virion core } \\
\text { protein }\end{array}$ & 86.533 & 100 & 347 & 348 & 348 & \\
\hline & SWPV2-144 & CNPV149 & $\begin{array}{l}\text { CNPV149 putative } \\
\text { thioredoxin binding } \\
\text { protein }\end{array}$ & & 99.673 & & 306 & 306 & \\
\hline & & CNPV150 & $\begin{array}{l}\text { CNPV150 ankyrin } \\
\text { repeat protein }\end{array}$ & & & & & 351 & \\
\hline & SWPV2-145 & CNPV151 & $\begin{array}{l}\text { CNPV151 ankyrin } \\
\text { repeat protein }\end{array}$ & & 99.029 & & 412 & 412 & \\
\hline & SWPV2-146 & CNPV152 & $\begin{array}{l}\text { CNPV152 } \\
\text { hypothetical protein }\end{array}$ & & 98 & & 149 & 187 & $\begin{array}{l}\text { SWPV2: C-terminus } \\
\text { fragment, not likely } \\
\text { translated }\end{array}$ \\
\hline & SWPV2-147 & CNPV153 & $\begin{array}{l}\text { CNPV153 Rep-like } \\
\text { protein }\end{array}$ & & 99.359 & & 312 & 312 & \\
\hline SWPV1-139 & & & $\begin{array}{l}\text { CNPV159 N1R/p28- } \\
\text { like protein }\end{array}$ & 78.488 & & 333 & & 337 & \\
\hline SWPV1-140 & & & $\begin{array}{l}\text { FWPV121 CC } \\
\text { chemokine-like } \\
\text { protein }\end{array}$ & 46 & & 93 & & 121 & \\
\hline
\end{tabular}


Table 1 Shearwaterpox virus (SWPV) genome annotations and comparative analysis of ORFs relative to CNPV genomes (Continued)

\begin{tabular}{|c|c|c|c|c|c|c|c|c|c|}
\hline SWPV1-141 & SWPV2-148 & CNPV154 & $\begin{array}{l}\text { CNPV154 variola } \\
\text { B22R-like protein }\end{array}$ & 90.067 & 98.286 & 1939 & 875 & 1928 & $\begin{array}{l}\text { SWPV2: N-terminus } \\
\text { fragment/SWPV1: } \\
\text { Low } \\
\text { SNP Density }\end{array}$ \\
\hline \multirow[t]{11}{*}{ SWPV1-142 } & SWPV2-149 & CNPV155 & $\begin{array}{l}\text { CNPV155 variola } \\
\text { B22R-like protein }\end{array}$ & 82.427 & 99.454 & 1810 & 1831 & 1830 & \\
\hline & SWPV2-150 & CNPV156 & $\begin{array}{l}\text { CNPV156 } \\
\text { hypothetical protein }\end{array}$ & & 96.287 & & 834 & 832 & \\
\hline & \multirow[t]{4}{*}{ SWPV2-151 } & CNPV157 & $\begin{array}{l}\text { CNPV157 TGF-beta- } \\
\text { like protein }\end{array}$ & & 87.679 & & 343 & 349 & \\
\hline & & CNPV158 & $\begin{array}{l}\text { CNPV158 TGF-beta- } \\
\text { like protein }\end{array}$ & & & & & 172 & \\
\hline & & CNPV159 & $\begin{array}{l}\text { CNPV159 N1R/p28- } \\
\text { like protein }\end{array}$ & & & & & 337 & \\
\hline & & CNPV160 & $\begin{array}{l}\text { CNPV160 N1R/p28- } \\
\text { like protein }\end{array}$ & & & & & 396 & \\
\hline & SWPV2-152 & CNPV161 & $\begin{array}{l}\text { CNPV161 TGF-beta- } \\
\text { like protein }\end{array}$ & & 99.441 & & 358 & 358 & \\
\hline & \multirow[t]{3}{*}{ SWPV2-153 } & CNPV162 & $\begin{array}{l}\text { CNPV162 TGF-beta- } \\
\text { like protein }\end{array}$ & & 97.987 & & 149 & 149 & \\
\hline & & CNPV163 & $\begin{array}{l}\text { CNPV163 } \\
\text { hypothetical protein }\end{array}$ & & & & & 92 & \\
\hline & & CNPV164 & $\begin{array}{l}\text { CNPV164 } \\
\text { hypothetical protein }\end{array}$ & & & & & 98 & \\
\hline & SWPV2-154 & CNPV165 & $\begin{array}{l}\text { CNPV165 N1R/p28- } \\
\text { like protein }\end{array}$ & & 98.75 & & 320 & 346 & $\begin{array}{l}\text { SWPV2: C-terminus } \\
\text { fragment, not likely } \\
\text { translated }\end{array}$ \\
\hline SWPV1-143 & SWPV2-155 & CNPV166 & $\begin{array}{l}\text { CNPV166 lg-like do- } \\
\text { main protein }\end{array}$ & 96.812 & 95.652 & 345 & 345 & 345 & $\begin{array}{l}\text { SWPV1: Low SNP } \\
\text { Density }\end{array}$ \\
\hline \multirow[t]{2}{*}{ SWPV1-144 } & SWPV2-156 & CNPV167 & $\begin{array}{l}\text { CNPV167 lg-like do- } \\
\text { main protein }\end{array}$ & 94.767 & 88.372 & 172 & 168 & 171 & $\begin{array}{l}\text { SWPV1: Low SNP } \\
\text { Density }\end{array}$ \\
\hline & \multirow[t]{2}{*}{ SWPV2-157 } & CNPV168 & $\begin{array}{l}\text { CNPV168 N1R/p28- } \\
\text { like protein }\end{array}$ & & 96 & & 350 & 358 & \\
\hline SWPV1-145 & & CNPV169 & $\begin{array}{l}\text { CNPV169 N1R/p28- } \\
\text { like protein }\end{array}$ & 83.578 & & 337 & & 332 & $\begin{array}{l}\text { SWPV1: CNPV-168/ } \\
169 \text { Fusion }\end{array}$ \\
\hline SWPV1-146 & SWPV2-158 & CNPV170 & $\begin{array}{l}\text { CNPV170 thymidylate } \\
\text { kinase }\end{array}$ & 100 & 100 & 121 & 212 & 212 & $\begin{array}{l}\text { SWPV1: N-terminus } \\
\text { fragment }\end{array}$ \\
\hline SWPV1-147 & SWPV2-159 & CNPV171 & $\begin{array}{l}\text { CNPV171 late } \\
\text { transcription factor } \\
\text { VLTF-1 }\end{array}$ & 96.923 & 100 & 260 & 260 & 260 & \\
\hline SWPV1-148 & SWPV2-160 & CNPV172 & $\begin{array}{l}\text { CNPV172 putative } \\
\text { myristylated protein }\end{array}$ & 83.125 & 99.403 & 336 & 335 & 335 & \\
\hline SWPV1-149 & SWPV2-161 & CNPV173 & $\begin{array}{l}\text { CNPV173 putative } \\
\text { myristylated IMV } \\
\text { envelope protein }\end{array}$ & 91.358 & 98.354 & 243 & 243 & 243 & \\
\hline SWPV1-150 & SWPV2-162 & CNPV174 & $\begin{array}{l}\text { CNPV174 conserved } \\
\text { hypothetical protein }\end{array}$ & 47.917 & 100 & 96 & 96 & 96 & \\
\hline SWPV1-151 & SWPV2-163 & CNPV175 & $\begin{array}{l}\text { CNPV175 conserved } \\
\text { hypothetical protein }\end{array}$ & 84.158 & 100 & 303 & 303 & 303 & \\
\hline SWPV1-152 & SWPV2-164 & CNPV176 & $\begin{array}{l}\text { CNPV176 DNA- } \\
\text { binding virion core } \\
\text { protein }\end{array}$ & 87.747 & 100 & 253 & 252 & 252 & \\
\hline SWPV1-153 & SWPV2-165 & CNPV177 & $\begin{array}{l}\text { CNPV177 conserved } \\
\text { hypothetical protein }\end{array}$ & 84.733 & 100 & 131 & 130 & 130 & \\
\hline
\end{tabular}


Table 1 Shearwaterpox virus (SWPV) genome annotations and comparative analysis of ORFs relative to CNPV genomes (Continued)

\begin{tabular}{|c|c|c|c|c|c|c|c|c|}
\hline SWPV1-154 & SWPV2-166 & CNPV178 & $\begin{array}{l}\text { CNPV178 putative } \\
\text { IMV membrane } \\
\text { protein }\end{array}$ & 85.135 & 100 & 148 & 148 & 148 \\
\hline SWPV1-155 & SWPV2-167 & CNPV179 & $\begin{array}{l}\text { CNPV179 poly(A) } \\
\text { polymerase small } \\
\text { subunit PAPS }\end{array}$ & 88.667 & 100 & 300 & 302 & 302 \\
\hline SWPV1-156 & SWPV2-168 & CNPV180 & $\begin{array}{l}\text { CNPV180 RNA } \\
\text { polymerase subunit } \\
\text { RPO22 }\end{array}$ & 87.634 & 99.462 & 186 & 186 & 186 \\
\hline SWPV1-157 & SWPV2-169 & CNPV181 & $\begin{array}{l}\text { CNPV181 conserved } \\
\text { hypothetical protein }\end{array}$ & 82.353 & 100 & 136 & 136 & 136 \\
\hline SWPV1-158 & SWPV2-170 & CNPV182 & $\begin{array}{l}\text { CNPV182 RNA } \\
\text { polymerase subunit } \\
\text { RPO147 }\end{array}$ & 93.866 & 99.922 & 1288 & 1288 & 1288 \\
\hline SWPV1-159 & SWPV2-171 & CNPV183 & $\begin{array}{l}\text { CNPV183 putative } \\
\text { protein-tyrosine } \\
\text { phosphatase, virus } \\
\text { assembly }\end{array}$ & 85.542 & 100 & 166 & 166 & 166 \\
\hline SWPV1-160 & SWPV2-172 & CNPV184 & $\begin{array}{l}\text { CNPV184 conserved } \\
\text { hypothetical protein }\end{array}$ & 91.534 & 100 & 190 & 189 & 189 \\
\hline SWPV1-161 & SWPV2-173 & CNPV185 & $\begin{array}{l}\text { CNPV185 ankyrin } \\
\text { repeat protein }\end{array}$ & 32.632 & 96.341 & 337 & 328 & 328 \\
\hline SWPV1-162 & SWPV2-174 & CNPV186 & $\begin{array}{l}\text { CNPV186 IMV } \\
\text { envelope protein }\end{array}$ & 100 & 100 & 329 & 330 & 330 \\
\hline SWPV1-163 & SWPV2-175 & CNPV187 & $\begin{array}{l}\text { CNPV187 RNA } \\
\text { polymerase } \\
\text { associated protein } \\
\text { RAP94 }\end{array}$ & 91.114 & 99.75 & 799 & 799 & 799 \\
\hline SWPV1-164 & SWPV2-176 & CNPV188 & $\begin{array}{l}\text { CNPV188 late } \\
\text { transcription factor } \\
\text { VLTF-4 }\end{array}$ & 70.115 & 92.941 & 170 & 170 & 170 \\
\hline SWPV1-165 & SWPV2-177 & CNPV189 & $\begin{array}{l}\text { CNPV189 DNA } \\
\text { topoisomerase }\end{array}$ & 88.608 & 99.684 & 316 & 316 & 316 \\
\hline SWPV1-166 & SWPV2-178 & CNPV190 & $\begin{array}{l}\text { CNPV190 conserved } \\
\text { hypothetical protein }\end{array}$ & 77.124 & 99.346 & 153 & 153 & 153 \\
\hline SWPV1-167 & SWPV2-179 & CNPV191 & $\begin{array}{l}\text { CNPV191 conserved } \\
\text { hypothetical protein }\end{array}$ & 70.874 & 99.029 & 103 & 103 & 103 \\
\hline SWPV1-168 & SWPV2-180 & CNPV192 & $\begin{array}{l}\text { CNPV192 mRNA } \\
\text { capping enzyme } \\
\text { large subunit }\end{array}$ & 88.221 & 99.764 & 848 & 846 & 846 \\
\hline SWPV1-169 & SWPV2-181 & CNPV193 & $\begin{array}{l}\text { CNPV193 HT motif } \\
\text { protein }\end{array}$ & 72.619 & 100 & 104 & 106 & 106 \\
\hline SWPV1-170 & SWPV2-182 & CNPV194 & $\begin{array}{l}\text { CNPV194 virion } \\
\text { protein }\end{array}$ & 71.223 & 100 & 139 & 140 & 140 \\
\hline SWPV1-171 & SWPV2-183 & CNPV195 & $\begin{array}{l}\text { CNPV195 } \\
\text { hypothetical protein }\end{array}$ & 51.2 & 98.611 & 139 & 144 & 144 \\
\hline SWPV1-172 & SWPV2-184 & CNPV196 & $\begin{array}{l}\text { CNPV196 conserved } \\
\text { hypothetical protein }\end{array}$ & 62.963 & 100 & 189 & 190 & 190 \\
\hline SWPV1-173 & SWPV2-185 & CNPV197 & $\begin{array}{l}\text { CNPV197 N1R/p28- } \\
\text { like protein }\end{array}$ & 61.679 & 97.818 & 279 & 275 & 275 \\
\hline SWPV1-174 & SWPV2-186 & CNPV198 & $\begin{array}{l}\text { CNPV198 C-type } \\
\text { lectin-like protein }\end{array}$ & 55.844 & 99.359 & 159 & 156 & 156 \\
\hline SWPV1-175 & SWPV2-187 & CNPV199 & $\begin{array}{l}\text { CNPV199 } \\
\text { deoxycytidine kinase- } \\
\text { like protein }\end{array}$ & 79.111 & 100 & 222 & 225 & 225 \\
\hline SWPV1-176 & SWPV2-188 & CNPV200 & $\begin{array}{l}\text { CNPV200 Rep-like } \\
\text { protein }\end{array}$ & 72.903 & 97.59 & 152 & 166 & 166 \\
\hline
\end{tabular}


Table 1 Shearwaterpox virus (SWPV) genome annotations and comparative analysis of ORFs relative to CNPV genomes (Continued)

\begin{tabular}{|c|c|c|c|c|c|c|c|c|c|}
\hline SWPV1-177 & SWPV2-189 & CNPV201 & $\begin{array}{l}\text { CNPV201 conserved } \\
\text { hypothetical protein }\end{array}$ & 60 & 97.661 & 197 & 167 & 192 & \\
\hline SWPV1-178 & SWPV2-190 & CNPV202 & $\begin{array}{l}\text { CNPV202 N1R/p28- } \\
\text { like protein }\end{array}$ & 69.203 & 99.638 & 275 & 276 & 276 & \\
\hline SWPV1-179 & SWPV2-191 & CNPV203 & $\begin{array}{l}\text { CNPV203 N1R/p28- } \\
\text { like protein }\end{array}$ & 64.935 & 99.738 & 380 & 382 & 382 & \\
\hline SWPV1-180 & SWPV2-192 & CNPV204 & $\begin{array}{l}\text { CNPV204 conserved } \\
\text { hypothetical protein }\end{array}$ & 53.226 & 100 & 53 & 61 & 61 & \\
\hline SWPV1-181 & SWPV2-193 & CNPV205 & $\begin{array}{l}\text { CNPV205 N1R/p28- } \\
\text { like protein }\end{array}$ & 71.885 & 99.371 & 317 & 318 & 318 & \\
\hline SWPV1-182 & SWPV2-194 & CNPV206 & $\begin{array}{l}\text { CNPV206 putative } \\
\text { photolyase }\end{array}$ & 84.989 & 99.364 & 464 & 472 & 472 & \\
\hline SWPV1-183 & & & $\begin{array}{l}\text { CNPV081 lg-like do- } \\
\text { main protein }\end{array}$ & 53.988 & & 332 & & 333 & \\
\hline SWPV1-184 & SWPV2-195 & CNPV207 & $\begin{array}{l}\text { CNPV207 N1R/p28- } \\
\text { like protein }\end{array}$ & 64.535 & 98.235 & 193 & 173 & 183 & \\
\hline SWPV1-185 & SWPV2-196 & CNPV208 & $\begin{array}{l}\text { CNPV208 conserved } \\
\text { hypothetical protein }\end{array}$ & 52.239 & 97.5 & 172 & 200 & 200 & \\
\hline SWPV1-186 & SWPV2-197 & CNPV209 & $\begin{array}{l}\text { CNPV209 N1R/p28- } \\
\text { like protein }\end{array}$ & 65.686 & 100 & 311 & 310 & 310 & \\
\hline SWPV1-187 & SWPV2-198 & CNPV210 & $\begin{array}{l}\text { CNPV210 N1R/p28- } \\
\text { like protein }\end{array}$ & 74.419 & 99.237 & 130 & 131 & 131 & \\
\hline SWPV1-188 & SWPV2-199 & CNPV211 & $\begin{array}{l}\text { CNPV211 conserved } \\
\text { hypothetical protein }\end{array}$ & 49.02 & 98.148 & 54 & 54 & 54 & \\
\hline SWPV1-189 & SWPV2-200 & CNPV212 & $\begin{array}{l}\text { CNPV212 N1R/p28- } \\
\text { like protein }\end{array}$ & 76.136 & 98.295 & 175 & 176 & 176 & \\
\hline SWPV1-190 & & & $\begin{array}{l}\text { no significant BLAST } \\
\text { hits }\end{array}$ & & & 70 & & & $\begin{array}{l}\text { SWPV1: Possible } \\
\text { Unique } \\
\text { ORF }\end{array}$ \\
\hline \multirow[t]{2}{*}{ SWPV1-191 } & SWPV2-201 & CNPV213 & $\begin{array}{l}\text { CNPV213 } \\
\text { deoxycytidine kinase- } \\
\text { like protein }\end{array}$ & 58.768 & 99.539 & 216 & 216 & 217 & \\
\hline & SWPV2-202 & CNPV214 & $\begin{array}{l}\text { CNPV214 vaccinia } \\
\text { C4L/C10L-like protein }\end{array}$ & & 99.438 & & 356 & 356 & \\
\hline SWPV1-192 & & & $\begin{array}{l}\text { CNPV012 conserved } \\
\text { hypothetical protein }\end{array}$ & 37.41 & & 165 & & 189 & \\
\hline SWPV1-193 & & & $\begin{array}{l}\text { CNPV223 ankyrin } \\
\text { repeat protein }\end{array}$ & 31.579 & & 674 & & 847 & \\
\hline \multirow[t]{3}{*}{ SWPV1-194 } & SWPV2-203 & CNPV215 & $\begin{array}{l}\text { CNPV215 CC } \\
\text { chemokine-like } \\
\text { protein }\end{array}$ & 49.751 & 96.078 & 202 & 204 & 204 & \\
\hline & SWPV2-204 & CNPV216 & $\begin{array}{l}\text { CNPV216 conserved } \\
\text { hypothetical protein }\end{array}$ & & 98.762 & & 401 & 404 & \\
\hline & SWPV2-205 & CNPV217 & $\begin{array}{l}\text { CNPV217 N1R/p28- } \\
\text { like protein }\end{array}$ & & 95.152 & & 330 & 330 & \\
\hline SWPV1-195 & & & $\begin{array}{l}\text { CNPV223 ankyrin } \\
\text { repeat protein }\end{array}$ & 38.474 & & 729 & & 847 & $\begin{array}{l}\text { SWPV1: N-terminus } \\
\text { fragment }\end{array}$ \\
\hline SWPV1-196 & SWPV2-206 & CNPV218 & $\begin{array}{l}\text { CNPV218 N1R/p28- } \\
\text { like protein }\end{array}$ & 66.667 & 99.522 & 318 & 223 & 437 & $\begin{array}{l}\text { SWPV2: N-terminus } \\
\text { fragment }\end{array}$ \\
\hline SWPV1-197 & & & $\begin{array}{l}\text { CNPV228 N1R/p28- } \\
\text { like protein }\end{array}$ & 53 & & 161 & & 371 & $\begin{array}{l}\text { SWPV1: N-terminus } \\
\text { fragment }\end{array}$ \\
\hline SWPV1-198 & & & $\begin{array}{l}\text { CNPV160 N1R/p28- } \\
\text { like protein }\end{array}$ & 79.293 & & 367 & & 396 & $\begin{array}{l}\text { SWPV1: Fragment/ } \\
\text { CNPV-220/221 Fusion }\end{array}$ \\
\hline SWPV1-199 & & & $\begin{array}{l}\text { CNPV160 N1R/p28- } \\
\text { like protein }\end{array}$ & 66.582 & & 360 & & 396 & $\begin{array}{l}\text { SWPV1: Paralog to } \\
\text { SWPV1-198? }\end{array}$ \\
\hline
\end{tabular}


Table 1 Shearwaterpox virus (SWPV) genome annotations and comparative analysis of ORFs relative to CNPV genomes (Continued)

\begin{tabular}{|c|c|c|c|c|c|c|c|c|c|}
\hline SWPV1-200 & & & $\begin{array}{l}\text { CNPV161 TGF-beta- } \\
\text { like protein }\end{array}$ & 36.882 & & 256 & & 358 & \\
\hline SWPV1-201 & & & $\begin{array}{l}\text { CNPV162 TGF-beta- } \\
\text { like protein }\end{array}$ & 50 & & 141 & & 149 & \\
\hline \multirow[t]{6}{*}{ SWPV1-202 } & & & $\begin{array}{l}\text { no significant BLAST } \\
\text { hits }\end{array}$ & & & 98 & & & $\begin{array}{l}\text { SWPV1: Possible } \\
\text { Unique ORF }\end{array}$ \\
\hline & SWPV2-207 & CNPV219 & $\begin{array}{l}\text { CNPV219 N1R/p28- } \\
\text { like protein }\end{array}$ & & 99.713 & & 349 & 349 & \\
\hline & SWPV2-208 & CNPV220 & $\begin{array}{l}\text { CNPV220 N1R/p28- } \\
\text { like protein }\end{array}$ & & 80.263 & & 85 & 178 & $\begin{array}{l}\text { SWPV2: N-terminus } \\
\text { fragment }\end{array}$ \\
\hline & SWPV2-209 & CNPV221 & $\begin{array}{l}\text { CNPV221 N1R/p28- } \\
\text { like protein }\end{array}$ & & 94.231 & & 213 & 281 & $\begin{array}{l}\text { SWPV2: N-terminus } \\
\text { fragment }\end{array}$ \\
\hline & SWPV2-210 & CNPV222 & $\begin{array}{l}\text { CNPV222 N1R/p28- } \\
\text { like protein }\end{array}$ & & 99.649 & & 285 & 285 & \\
\hline & SWPV2-211 & CNPV223 & $\begin{array}{l}\text { CNPV223 ankyrin } \\
\text { repeat protein }\end{array}$ & & 98.819 & & 847 & 847 & \\
\hline \multirow[t]{5}{*}{ SWPV1-203 } & SWPV2-212 & CNPV224 & $\begin{array}{l}\text { CNPV224 } \\
\text { hypothetical protein }\end{array}$ & 50.382 & 100 & 126 & 239 & 239 & \\
\hline & SWPV2-213 & CNPV225 & $\begin{array}{l}\text { CNPV225 N1R/p28- } \\
\text { like protein }\end{array}$ & & 74.038 & & 94 & 159 & $\begin{array}{l}\text { SWPV2: N-terminus } \\
\text { fragment }\end{array}$ \\
\hline & SWPV2-214 & CNPV226 & $\begin{array}{l}\text { CNPV226 N1R/p28- } \\
\text { like protein }\end{array}$ & & 96.825 & & 126 & 134 & \\
\hline & & CNPV227 & $\begin{array}{l}\text { CNPV227 N1R/p28- } \\
\text { like protein }\end{array}$ & & & & & 359 & \\
\hline & & CNPV228 & $\begin{array}{l}\text { CNPV228 N1R/p28- } \\
\text { like protein }\end{array}$ & & & & & 371 & \\
\hline \multirow[t]{2}{*}{ SWPV1-204 } & SWPV2-215 & CNPV229 & $\begin{array}{l}\text { CNPV229 ankyrin } \\
\text { repeat protein }\end{array}$ & 44.498 & 97.926 & 423 & 434 & 434 & \\
\hline & SWPV2-216 & CNPV230 & $\begin{array}{l}\text { CNPV230 } \\
\text { hypothetical protein }\end{array}$ & & 98.462 & & 65 & 65 & \\
\hline SWPV1-205 & SWPV2-217 & CNPV231 & $\begin{array}{l}\text { CNPV231 MyD116- } \\
\text { like domain protein }\end{array}$ & 72.222 & 98.101 & 100 & 158 & 158 & $\begin{array}{l}\text { SWPV1: large in- } \\
\text { frame deletions }\end{array}$ \\
\hline SWPV1-206 & SWPV2-218 & CNPV232 & $\begin{array}{l}\text { CNPV232 CC } \\
\text { chemokine-like } \\
\text { protein }\end{array}$ & 59.024 & 93.137 & 205 & 204 & 204 & \\
\hline \multirow[t]{2}{*}{ SWPV1-207 } & SWPV2-219 & CNPV233 & $\begin{array}{l}\text { CNPV233 ankyrin } \\
\text { repeat protein }\end{array}$ & 56.936 & 99.788 & 476 & 471 & 471 & \\
\hline & SWPV2-220 & CNPV234 & $\begin{array}{l}\text { CNPV234 ankyrin } \\
\text { repeat protein }\end{array}$ & & 100 & & 508 & 508 & $\begin{array}{l}\text { SWPV2: High SNP } \\
\text { Density }\end{array}$ \\
\hline \multirow[t]{2}{*}{ SWPV1-208 } & & & $\begin{array}{l}\text { PEPV008 vaccinia } \\
\text { C4L/C10L-like protein }\end{array}$ & 55 & & 420 & & 411 & \\
\hline & SWPV2-221 & CNPV235 & $\begin{array}{l}\text { CNPV235 conserved } \\
\text { hypothetical protein }\end{array}$ & & 88.426 & & 432 & 432 & \\
\hline \multirow[t]{2}{*}{ SWPV1-209 } & SWPV2-222 & CNPV236 & $\begin{array}{l}\text { CNPV236 } \\
\text { ribonucleotide } \\
\text { reductase small } \\
\text { subunit }\end{array}$ & 83.282 & 95.666 & 324 & 323 & 323 & \\
\hline & SWPV2-223 & CNPV237 & $\begin{array}{l}\text { CNPV237 ankyrin } \\
\text { repeat protein }\end{array}$ & & 97.732 & & 441 & 441 & \\
\hline SWPV1-210 & & & $\begin{array}{l}\text { CNPV234 ankyrin } \\
\text { repeat protein }\end{array}$ & 30.545 & & 559 & & 508 & \\
\hline SWPV1-211 & SWPV2-224 & CNPV238 & $\begin{array}{l}\text { CNPV238 late } \\
\text { transcription factor } \\
\text { VLTF-3 }\end{array}$ & 95.111 & 100 & 225 & 225 & 225 & \\
\hline SWPV1-212 & SWPV2-225 & CNPV239 & $\begin{array}{l}\text { CNPV239 virion redox } \\
\text { protein }\end{array}$ & 80.282 & 100 & 72 & 75 & 75 & \\
\hline
\end{tabular}


Table 1 Shearwaterpox virus (SWPV) genome annotations and comparative analysis of ORFs relative to CNPV genomes (Continued)

\begin{tabular}{|c|c|c|c|c|c|c|c|c|c|}
\hline SWPV1-213 & SWPV2-226 & CNPV240 & $\begin{array}{l}\text { CNPV240 virion core } \\
\text { protein P4b }\end{array}$ & 88.788 & 99.848 & 660 & 659 & 659 & \\
\hline SWPV1-214 & SWPV2-227 & CNPV241 & $\begin{array}{l}\text { CNPV241 } \\
\text { immunodominant } \\
\text { virion protein }\end{array}$ & 47.368 & 99.07 & 242 & 215 & 215 & \\
\hline SWPV1-215 & SWPV2-228 & CNPV242 & $\begin{array}{l}\text { CNPV242 RNA } \\
\text { polymerase subunit } \\
\text { RPO19 }\end{array}$ & 88.166 & 98.817 & 169 & 169 & 169 & \\
\hline SWPV1-216 & SWPV2-229 & CNPV243 & $\begin{array}{l}\text { CNPV243 conserved } \\
\text { hypothetical protein }\end{array}$ & 81.501 & 98.928 & 373 & 373 & 373 & \\
\hline SWPV1-217 & SWPV2-230 & CNPV244 & $\begin{array}{l}\text { CNPV244 early } \\
\text { transcription factor } \\
\text { large subunit VETFL }\end{array}$ & 95.91 & 100 & 709 & 709 & 709 & \\
\hline SWPV1-218 & SWPV2-231 & CNPV245 & $\begin{array}{l}\text { CNPV245 } \\
\text { intermediate } \\
\text { transcription factor } \\
\text { VITF-3 }\end{array}$ & 90.667 & 99.667 & 300 & 300 & 300 & \\
\hline SWPV1-219 & SWPV2-232 & CNPV246 & $\begin{array}{l}\text { CNPV246 putative } \\
\text { IMV membrane } \\
\text { protein }\end{array}$ & 80 & 98.667 & 76 & 75 & 75 & \\
\hline SWPV1-220 & SWPV2-233 & CNPV247 & $\begin{array}{l}\text { CNPV247 virion core } \\
\text { protein P4a }\end{array}$ & 81.494 & 99.664 & 897 & 893 & 893 & \\
\hline SWPV1-221 & SWPV2-234 & CNPV248 & $\begin{array}{l}\text { CNPV248 conserved } \\
\text { hypothetical protein }\end{array}$ & 78.723 & 100 & 281 & 279 & 279 & \\
\hline SWPV1-222 & SWPV2-235 & CNPV249 & $\begin{array}{l}\text { CNPV249 virion } \\
\text { protein }\end{array}$ & 74.269 & 99.405 & 167 & 168 & 168 & \\
\hline SWPV1-223 & SWPV2-236 & CNPV250 & $\begin{array}{l}\text { CNPV250 conserved } \\
\text { hypothetical protein }\end{array}$ & 36.082 & 94.595 & 73 & 56 & 99 & $\begin{array}{l}\text { SWPV2: N-terminus } \\
\text { fragment }\end{array}$ \\
\hline SWPV1-224 & SWPV2-237 & CNPV251 & $\begin{array}{l}\text { CNPV251 putative } \\
\text { IMV membrane } \\
\text { protein }\end{array}$ & 69.565 & 100 & 69 & 69 & 69 & \\
\hline SWPV1-225 & SWPV2-238 & CNPV252 & $\begin{array}{l}\text { CNPV252 putative } \\
\text { IMV membrane } \\
\text { protein }\end{array}$ & 68.478 & 98.913 & 92 & 92 & 92 & \\
\hline SWPV1-226 & SWPV2-239 & CNPV253 & $\begin{array}{l}\text { CNPV253 putative } \\
\text { IMV membrane } \\
\text { virulence factor }\end{array}$ & 73.585 & 98.113 & 53 & 53 & 53 & \\
\hline SWPV1-227 & SWPV2-240 & CNPV254 & $\begin{array}{l}\text { CNPV254 conserved } \\
\text { hypothetical protein }\end{array}$ & 75 & 98.958 & 96 & 96 & 96 & \\
\hline SWPV1-228 & SWPV2-241 & CNPV255 & $\begin{array}{l}\text { CNPV255 predicted } \\
\text { myristylated protein }\end{array}$ & 84.282 & 99.728 & 368 & 368 & 368 & \\
\hline SWPV1-229 & SWPV2-242 & CNPV256 & $\begin{array}{l}\text { CNPV256 putative } \\
\text { phosphorylated IMV } \\
\text { membrane protein }\end{array}$ & 81.006 & 100 & 188 & 192 & 192 & \\
\hline SWPV1-230 & SWPV2-243 & CNPV257 & $\begin{array}{l}\text { CNPV257 DNA } \\
\text { helicase, } \\
\text { transcriptional } \\
\text { elongation }\end{array}$ & 87.229 & 99.784 & 462 & 462 & 462 & \\
\hline SWPV1-231 & SWPV2-244 & CNPV258 & $\begin{array}{l}\text { CNPV258 conserved } \\
\text { hypothetical protein }\end{array}$ & 77.647 & 100 & 86 & 89 & 89 & \\
\hline SWPV1-232 & SWPV2-245 & CNPV259 & $\begin{array}{l}\text { CNPV259 DNA } \\
\text { polymerase } \\
\text { processivity factor }\end{array}$ & 81.86 & 100 & 432 & 112 & 434 & \\
\hline SWPV1-233 & SWPV2-246 & CNPV260 & $\begin{array}{l}\text { CNPV260 conserved } \\
\text { hypothetical protein }\end{array}$ & 91.071 & 99.77 & 112 & 434 & 112 & \\
\hline SWPV1-234 & SWPV2-247 & CNPV261 & $\begin{array}{l}\text { CNPV261 Holliday } \\
\text { junction resolvase } \\
\text { protein }\end{array}$ & 80.405 & 100 & 151 & 152 & 152 & \\
\hline
\end{tabular}


Table 1 Shearwaterpox virus (SWPV) genome annotations and comparative analysis of ORFs relative to CNPV genomes (Continued)

\begin{tabular}{|c|c|c|c|c|c|c|c|c|}
\hline SWPV1-235 & SWPV2-248 & CNPV262 & $\begin{array}{l}\text { CNPV262 } \\
\text { intermediate } \\
\text { transcription factor } \\
\text { VITF-3 }\end{array}$ & 86.126 & 100 & 383 & 383 & 383 \\
\hline SWPV1-236 & SWPV2-249 & CNPV263 & $\begin{array}{l}\text { CNPV263 RNA } \\
\text { polymerase subunit } \\
\text { RPO132 }\end{array}$ & 94.301 & 100 & 1158 & 1157 & 1157 \\
\hline SWPV1-237 & SWPV2-250 & CNPV264 & $\begin{array}{l}\text { CNPV264 A type } \\
\text { inclusion-like protein }\end{array}$ & 81.015 & 99.502 & 602 & 601 & 603 \\
\hline SWPV1-238 & SWPV2-251 & CNPV265 & $\begin{array}{l}\text { CNPV265 A type } \\
\text { inclusion-like/fusion } \\
\text { protein }\end{array}$ & 67.015 & 99.789 & 471 & 475 & 475 \\
\hline SWPV1-239 & SWPV2-252 & CNPV266 & $\begin{array}{l}\text { CNPV266 conserved } \\
\text { hypothetical protein }\end{array}$ & 89.286 & 99.286 & 140 & 140 & 140 \\
\hline SWPV1-240 & SWPV2-253 & CNPV267 & $\begin{array}{l}\text { CNPV267 RNA } \\
\text { polymerase subunit } \\
\text { RPO35 }\end{array}$ & 77.558 & 99.016 & 303 & 305 & 305 \\
\hline SWPV1-241 & SWPV2-254 & CNPV268 & $\begin{array}{l}\text { CNPV268 conserved } \\
\text { hypothetical protein }\end{array}$ & 73.529 & 100 & 72 & 75 & 75 \\
\hline SWPV1-242 & SWPV2-255 & CNPV269 & $\begin{array}{l}\text { CNPV269 conserved } \\
\text { hypothetical protein }\end{array}$ & 70.796 & 100 & 113 & 113 & 113 \\
\hline SWPV1-243 & SWPV2-256 & CNPV270 & $\begin{array}{l}\text { CNPV270 conserved } \\
\text { hypothetical protein }\end{array}$ & 70.588 & 100 & 119 & 120 & 120 \\
\hline SWPV1-244 & SWPV2-257 & CNPV271 & $\begin{array}{l}\text { CNPV271 DNA } \\
\text { packaging protein }\end{array}$ & 89.963 & 99.648 & 272 & 284 & 284 \\
\hline SWPV1-245 & SWPV2-258 & CNPV272 & $\begin{array}{l}\text { CNPV272 C-type } \\
\text { lectin-like EEV protein }\end{array}$ & 76.136 & 99.448 & 182 & 181 & 181 \\
\hline SWPV1-246 & & & $\begin{array}{l}\text { CNPV } 012 \text { conserved } \\
\text { hypothetical protein }\end{array}$ & 30.147 & & 172 & & 189 \\
\hline SWPV1-247 & SWPV2-259 & CNPV273 & $\begin{array}{l}\text { CNPV273 conserved } \\
\text { hypothetical protein }\end{array}$ & 62.816 & 99.635 & 276 & 274 & 274 \\
\hline SWPV1-248 & SWPV2-260 & CNPV274 & $\begin{array}{l}\text { CNPV274 putative } \\
\text { tyrosine protein } \\
\text { kinase }\end{array}$ & 63.197 & 99.628 & 286 & 269 & 269 \\
\hline SWPV1-249 & SWPV2-261 & CNPV275 & $\begin{array}{l}\text { CNPV275 putative } \\
\text { serpin }\end{array}$ & 72.271 & 99.408 & 340 & 338 & 338 \\
\hline SWPV1-250 & SWPV2-262 & CNPV276 & $\begin{array}{l}\text { CNPV276 conserved } \\
\text { hypothetical protein }\end{array}$ & 56.667 & 100 & 227 & 252 & 252 \\
\hline SWPV1-251 & SWPV2-263 & CNPV277 & $\begin{array}{l}\text { CNPV277 G protein- } \\
\text { coupled receptor-like } \\
\text { protein }\end{array}$ & 90 & 99.677 & 310 & 310 & 310 \\
\hline SWPV1-252 & SWPV2-264 & CNPV278 & $\begin{array}{l}\text { CNPV278 conserved } \\
\text { hypothetical protein }\end{array}$ & 89.691 & 98.958 & 97 & 96 & 96 \\
\hline SWPV1-253 & SWPV2-265 & CNPV279 & $\begin{array}{l}\text { CNPV279 beta-NGF- } \\
\text { like protein }\end{array}$ & 63.415 & 100 & 167 & 169 & 169 \\
\hline SWPV1-254 & SWPV2-266 & CNPV280 & $\begin{array}{l}\text { CNPV280 HT motif } \\
\text { protein }\end{array}$ & 67.692 & 99.231 & 134 & 130 & 130 \\
\hline SWPV1-255 & SWPV2-267 & CNPV281 & $\begin{array}{l}\text { CNPV281 conserved } \\
\text { hypothetical protein }\end{array}$ & 71.728 & 99.533 & 192 & 214 & 214 \\
\hline SWPV1-256 & SWPV2-268 & CNPV282 & $\begin{array}{l}\text { CNPV282 HT motif } \\
\text { protein }\end{array}$ & 71.552 & 100 & 118 & 120 & 120 \\
\hline SWPV1-257 & SWPV2-269 & CNPV283 & $\begin{array}{l}\text { CNPV283 CC } \\
\text { chemokine-like } \\
\text { protein }\end{array}$ & 63.208 & 100 & 110 & 111 & 111 \\
\hline SWPV1-258 & SWPV2-270 & CNPV284 & $\begin{array}{l}\text { CNPV284 putative } \\
\text { interleukin binding } \\
\text { protein }\end{array}$ & 37.405 & 90.769 & 192 & 193 & 195 \\
\hline
\end{tabular}


Table 1 Shearwaterpox virus (SWPV) genome annotations and comparative analysis of ORFs relative to CNPV genomes (Continued)

\begin{tabular}{|c|c|c|c|c|c|c|c|c|}
\hline SWPV1-259 & SWPV2-271 & CNPV285 & $\begin{array}{l}\text { CNPV285 EGF-like } \\
\text { protein }\end{array}$ & 62.992 & 99.206 & 123 & 126 & 126 \\
\hline SWPV1-260 & SWPV2-272 & CNPV286 & $\begin{array}{l}\text { CNPV286 putative } \\
\text { serine/threonine } \\
\text { protein kinase }\end{array}$ & 76.744 & 99.672 & 303 & 305 & 305 \\
\hline SWPV1-261 & SWPV2-273 & CNPV287 & $\begin{array}{l}\text { CNPV287 conserved } \\
\text { hypothetical protein }\end{array}$ & 73.248 & 98.758 & 165 & 160 & 161 \\
\hline SWPV1-262 & SWPV2-274 & CNPV288 & $\begin{array}{l}\text { CNPV288 C-type } \\
\text { lectin-like protein }\end{array}$ & 52.414 & 88.435 & 163 & 147 & 147 \\
\hline SWPV1-263 & SWPV2-275 & CNPV289 & $\begin{array}{l}\text { CNPV289 putative } \\
\text { interleukin binding } \\
\text { protein }\end{array}$ & 58.993 & 99.281 & 132 & 139 & 139 \\
\hline SWPV1-264 & SWPV2-276 & CNPV290 & $\begin{array}{l}\text { CNPV290 conserved } \\
\text { hypothetical protein }\end{array}$ & 84 & 83.784 & 75 & 75 & 75 \\
\hline SWPV1-265 & SWPV2-277 & CNPV291 & $\begin{array}{l}\text { CNPV291 ankyrin } \\
\text { repeat protein }\end{array}$ & 48.067 & 98.99 & 613 & 594 & 594 \\
\hline SWPV1-266 & SWPV2-278 & CNPV292 & $\begin{array}{l}\text { CNPV292 } \\
\text { hypothetical protein }\end{array}$ & 37.209 & 100 & 101 & 74 & 74 \\
\hline SWPV1-267 & SWPV2-279 & CNPV293 & $\begin{array}{l}\text { CNPV293 ankyrin } \\
\text { repeat protein }\end{array}$ & 55.634 & 99.648 & 305 & 284 & 284 \\
\hline SWPV1-268 & SWPV2-280 & CNPV294 & $\begin{array}{l}\text { CNPV294 ankyrin } \\
\text { repeat protein }\end{array}$ & 68.447 & 99.07 & 424 & 430 & 430 \\
\hline SWPV1-269 & & & $\begin{array}{l}\text { PIPV223 host range } \\
\text { protein }\end{array}$ & 51 & & 138 & & 143 \\
\hline SWPV1-270 & & & $\begin{array}{l}\text { FWPV217 } \\
\text { hypothetical protein }\end{array}$ & 50 & & 330 & & 328 \\
\hline SWPV1-271 & SWPV2-281 & CNPV295 & $\begin{array}{l}\text { CNPV295 ankyrin } \\
\text { repeat protein }\end{array}$ & 57.736 & 100 & 264 & 396 & 396 \\
\hline SWPV1-272 & SWPV2-282 & CNPV296 & $\begin{array}{l}\text { CNPV296 ankyrin } \\
\text { repeat protein }\end{array}$ & 67.195 & 99.127 & 438 & 458 & 458 \\
\hline SWPV1-273 & SWPV2-283 & CNPV297 & $\begin{array}{l}\text { CNPV297 ankyrin } \\
\text { repeat protein }\end{array}$ & 54.972 & 99.457 & 717 & 737 & 737 \\
\hline SWPV1-274 & SWPV2-284 & CNPV298 & $\begin{array}{l}\text { CNPV298 ankyrin } \\
\text { repeat protein }\end{array}$ & 64.591 & 99.825 & 573 & 571 & 571 \\
\hline SWPV1-275 & SWPV2-285 & CNPV299 & $\begin{array}{l}\text { CNPV299 putative } \\
\text { serine/threonine } \\
\text { protein kinase }\end{array}$ & 67.893 & 99.333 & 303 & 300 & 300 \\
\hline SWPV1-276 & SWPV2-286 & CNPV300 & $\begin{array}{l}\text { CNPV300 ankyrin } \\
\text { repeat protein }\end{array}$ & 75.82 & 98.77 & 253 & 244 & 244 \\
\hline SWPV1-277 & & & $\begin{array}{l}\text { CNPV219 N1R/p28- } \\
\text { like protein }\end{array}$ & 28.467 & & 142 & & 349 \\
\hline SWPV1-278 & & & $\begin{array}{l}\text { CNPV228 N1R/p28- } \\
\text { like protein }\end{array}$ & 43.038 & & 87 & & 371 \\
\hline SWPV1-279 & & & $\begin{array}{l}\text { TKPV163 ankyrin } \\
\text { repeat protein }\end{array}$ & 40 & & 432 & & 434 \\
\hline SWPV1-280 & SWPV2-287 & CNPV301 & $\begin{array}{l}\text { CNPV301 ankyrin } \\
\text { repeat protein }\end{array}$ & 59.546 & 99.241 & 510 & 527 & 527 \\
\hline SWPV1-281 & SWPV2-288 & CNPV302 & $\begin{array}{l}\text { CNPV302 conserved } \\
\text { hypothetical protein }\end{array}$ & 45.026 & 100 & 175 & 193 & 193 \\
\hline SWPV1-282 & SWPV2-289 & CNPV303 & $\begin{array}{l}\text { CNPV303 ankyrin } \\
\text { repeat protein }\end{array}$ & 68.938 & 99.4 & 499 & 500 & 500 \\
\hline SWPV1-283 & SWPV2-290 & CNPV304 & $\begin{array}{l}\text { CNPV304 ankyrin } \\
\text { repeat protein }\end{array}$ & 62.105 & 99.785 & 476 & 466 & 466 \\
\hline SWPV1-284 & SWPV2-291 & CNPV305 & $\begin{array}{l}\text { CNPV305 N1R/p28- } \\
\text { like protein }\end{array}$ & 54.545 & 100 & 261 & 262 & 262 \\
\hline
\end{tabular}


Table 1 Shearwaterpox virus (SWPV) genome annotations and comparative analysis of ORFs relative to CNPV genomes (Continued)

\begin{tabular}{|c|c|c|c|c|c|c|c|c|c|}
\hline SWPV1-285 & SWPV2-292 & CNPV306 & $\begin{array}{l}\text { CNPV306 } \\
\text { hypothetical protein }\end{array}$ & 30.769 & 98.611 & 73 & 72 & 72 & \\
\hline SWPV1-286 & SWPV2-293 & CNPV307 & $\begin{array}{l}\text { CNPV307 C-type } \\
\text { lectin-like protein }\end{array}$ & 55.828 & 100 & 165 & 154 & 154 & \\
\hline SWPV1-287 & SWPV2-294 & CNPV308 & $\begin{array}{l}\text { CNPV308 ankyrin } \\
\text { repeat protein }\end{array}$ & 58.757 & 99.44 & 359 & 357 & 357 & \\
\hline SWPV1-288 & SWPV2-295 & CNPV309 & $\begin{array}{l}\text { CNPV309 ankyrin } \\
\text { repeat protein }\end{array}$ & 69.388 & 100 & 195 & 196 & 196 & \\
\hline SWPV1-289 & SWPV2-296 & CNPV310 & $\begin{array}{l}\text { CNPV310 ankyrin } \\
\text { repeat protein }\end{array}$ & 47.359 & 99.255 & 540 & 537 & 537 & \\
\hline SWPV1-290 & SWPV2-297 & CNPV311 & $\begin{array}{l}\text { CNPV311 EFc-like } \\
\text { protein }\end{array}$ & 54.4 & 99.194 & 125 & 124 & 124 & \\
\hline SWPV1-291 & SWPV2-298 & CNPV312 & $\begin{array}{l}\text { CNPV } 312 \text { conserved } \\
\text { hypothetical protein }\end{array}$ & 53.704 & 98.795 & 168 & 166 & 166 & \\
\hline SWPV1-292 & SWPV2-299 & CNPV313 & $\begin{array}{l}\text { CNPV313 lg-like do- } \\
\text { main protein }\end{array}$ & 69.43 & 98.165 & 213 & 218 & 218 & \\
\hline SWPV1-293 & SWPV2-300 & CNPV314 & $\begin{array}{l}\text { CNPV314 ankyrin } \\
\text { repeat protein }\end{array}$ & 71.552 & 99.829 & 580 & 629 & 584 & \\
\hline SWPV1-294 & & & $\begin{array}{l}\text { CNPV011 ankyrin } \\
\text { repeat protein }\end{array}$ & 32 & & 513 & & 586 & \\
\hline SWPV1-295 & SWPV2-301 & CNPV315 & $\begin{array}{l}\text { CNPV315 G protein- } \\
\text { coupled receptor-like } \\
\text { protein }\end{array}$ & 59.17 & 99.365 & 315 & 315 & 315 & \\
\hline SWPV1-296 & & & $\begin{array}{l}\text { CNPV014 lg-like do- } \\
\text { main protein }\end{array}$ & 59.624 & & 230 & & 490 & \\
\hline SWPV1-297 & & & $\begin{array}{l}\text { CNPV014 lg-like do- } \\
\text { main protein }\end{array}$ & 59.641 & & 240 & & 490 & \\
\hline SWPV1-298 & & & $\begin{array}{l}\text { CNPV015 ankyrin } \\
\text { repeat protein }\end{array}$ & 45.455 & & 74 & & 528 & \\
\hline SWPV1-299 & & & $\begin{array}{l}\text { CNPV150 ankyrin } \\
\text { repeat protein }\end{array}$ & 36.364 & & 84 & & 351 & \\
\hline \multirow[t]{4}{*}{ SWPV1-300 } & SWPV2-302 & CNPV316 & $\begin{array}{l}\text { CNPV316 ankyrin } \\
\text { repeat protein }\end{array}$ & 35.294 & 99.632 & 162 & 544 & 544 & \\
\hline & SWPV2-303 & CNPV317 & $\begin{array}{l}\text { CNPV317 } \\
\text { hypothetical protein }\end{array}$ & & 100 & & 55 & 55 & \\
\hline & SWPV2-304 & CNPV318 & $\begin{array}{l}\text { CNPV318 ankyrin } \\
\text { repeat protein }\end{array}$ & & 98.054 & & 514 & 514 & \\
\hline & SWPV2-305 & CNPV319 & $\begin{array}{l}\text { CNPV319 ankyrin } \\
\text { repeat protein }\end{array}$ & & 97.638 & & 637 & 739 & $\begin{array}{l}\text { SWPV2: C-terminus } \\
\text { fragment, not likely } \\
\text { translated }\end{array}$ \\
\hline SWPV1-301 & & & $\begin{array}{l}\text { PIPV253 EFc-like } \\
\text { protein }\end{array}$ & 69 & & 124 & & 124 & \\
\hline SWPV1-302 & & & $\begin{array}{l}\text { CNPV015 ankyrin } \\
\text { repeat protein }\end{array}$ & 45.276 & & 520 & & 528 & \\
\hline SWPV1-303 & & & $\begin{array}{l}\text { CNPV223 ankyrin } \\
\text { repeat protein }\end{array}$ & 40 & & 480 & & 847 & \\
\hline \multirow[t]{3}{*}{ SWPV1-304 } & SWPV2-306 & CNPV320 & $\begin{array}{l}\text { CNPV320 lg-like do- } \\
\text { main protein }\end{array}$ & 76.858 & 99.787 & 468 & 469 & 469 & \\
\hline & SWPV2-307 & CNPV321 & $\begin{array}{l}\text { CNPV321 EFc-like } \\
\text { protein }\end{array}$ & & 99.194 & & 124 & 124 & \\
\hline & SWPV2-308 & CNPV322 & $\begin{array}{l}\text { CNPV322 ankyrin } \\
\text { repeat protein }\end{array}$ & & 98.408 & & 689 & 690 & \\
\hline SWPV1-305 & & & $\begin{array}{l}\text { CNPV035 C-type } \\
\text { lectin-like protein }\end{array}$ & 35.556 & & 138 & & 134 & \\
\hline
\end{tabular}


Table 1 Shearwaterpox virus (SWPV) genome annotations and comparative analysis of ORFs relative to CNPV genomes (Continued)

\begin{tabular}{|c|c|c|c|c|c|c|c|c|}
\hline \multicolumn{3}{|l|}{ SWPV1-306 } & \multirow{2}{*}{$\begin{array}{l}\text { CNPV008 C-type } \\
\text { lectin-like protein } \\
\text { CNPV323 conserved } \\
\text { hypothetical protein }\end{array}$} & \multicolumn{2}{|l|}{50} & \multicolumn{2}{|l|}{174} & \multirow[t]{2}{*}{169} \\
\hline SWPV1-307 & SWPV2-309 & CNPV323 & & 75.61 & 93.651 & 84 & 186 & \\
\hline SWPV1-308 & SWPV2-310 & CNPV324 & $\begin{array}{l}\text { CNPV324 conserved } \\
\text { hypothetical protein }\end{array}$ & 87.387 & 99.55 & 220 & 222 & 222 \\
\hline SWPV1-309 & & CNPV325 & $\begin{array}{l}\text { CNPV325 ankyrin } \\
\text { repeat protein }\end{array}$ & 56.458 & & 468 & & 514 \\
\hline \multirow[t]{3}{*}{ SWPV1-310 } & SWPV2-311 & CNPV326 & $\begin{array}{l}\text { CNPV326 C-type } \\
\text { lectin-like protein }\end{array}$ & 32.044 & 85.99 & 181 & 208 & 204 \\
\hline & SWPV2-312 & CNPV327 & $\begin{array}{l}\text { CNPV } 327 \\
\text { hypothetical protein }\end{array}$ & & 92.941 & & 171 & 171 \\
\hline & & CNPV328 & $\begin{array}{l}\text { CNPV328 } \\
\text { hypothetical protein }\end{array}$ & & & & & 72 \\
\hline
\end{tabular}

brachyrhynchos) and American robin (Turdus migratorius) [24], which is almost identical to CPNV-1 within this relatively small fragment of the genome.

\section{Features of SWPV-2}

As noted above, and displayed in the Dotplot (Fig. 2b), SWPV-2 is very similar to CNPV with almost $98 \% \mathrm{nt}$ identity. However, a $1 \%$ difference still gives approximately 10 mutations in an average sized gene any of which could have drastic effects if an early STOP codon is introduced to the gene sequence. Similarly, small changes to promoter regions can significantly alter gene expressions that are impossible to predict in these viruses. With this annotation strategy, $18 \mathrm{CNPV}$ genes were deemed to be missing from the SWPV-2 complete genome and a further 15 genes significantly fragmented as to probably cause them to be non-functional (Table 1). No novel genes were predicted in SWPV-2, and no rearrangement of genes compared to CNPV was observed.

\section{Features of SWPV-1}

As expected from the much lower percent nt identity, SWPV-1 was found to be considerably more different to CNPV than SWPV-2 when compared at the level of genes present or absent. (Table 1). 43 CNPV genes are absent from SWPV-1 and a further 6 are significantly fragmented. There are 4 predicted genes in SWPV-1 that are not present in any other poxvirus, nor do they match
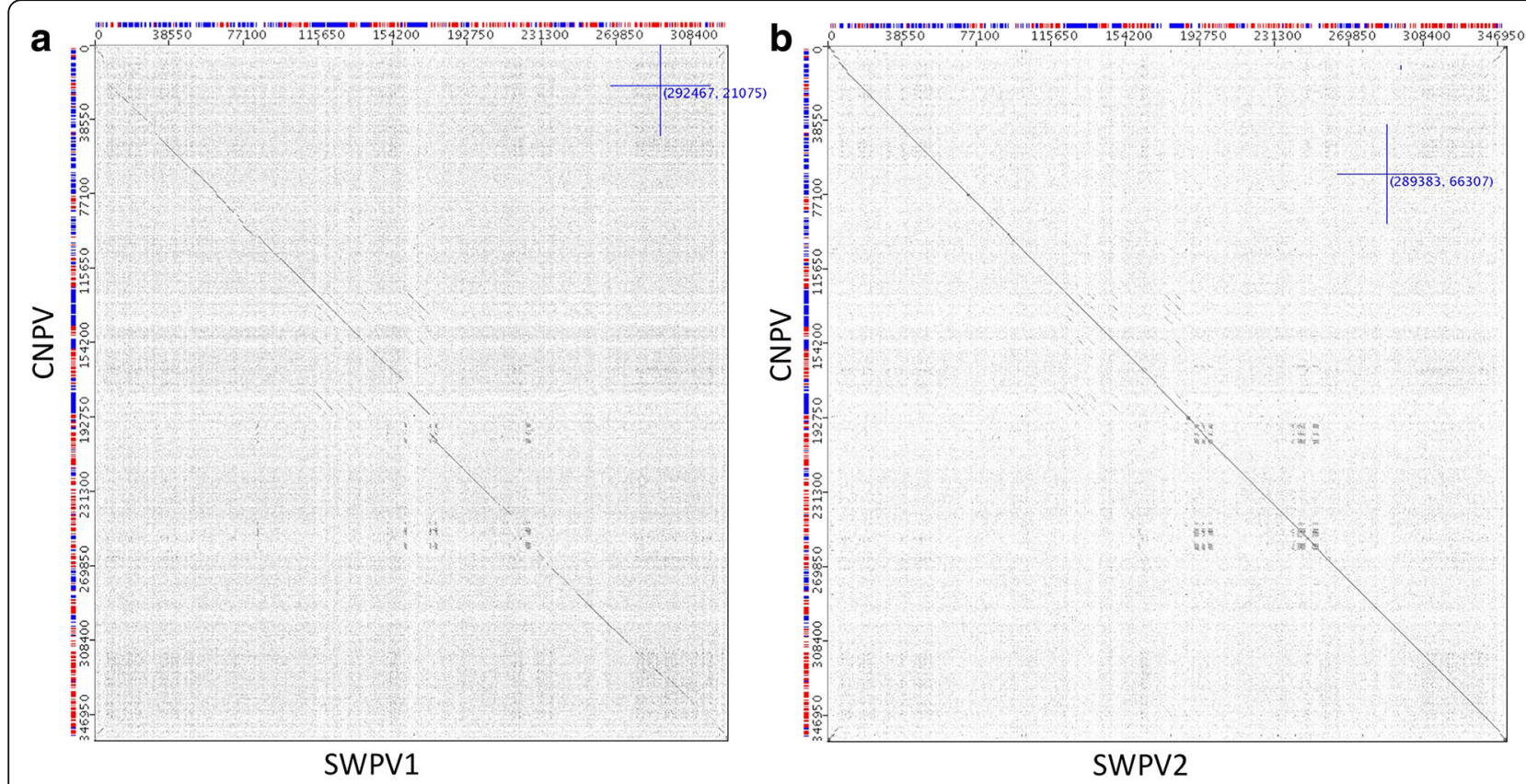

Fig. 2 Dotplots of Shearwaterpox viruses (SWPV-1 and 2) vs CNPV genomes. Horizontal sequence: SWPV-1 (a) and SWPV-2 (b), vertical sequence CNPV. Red and blue boxes represent genes transcribed to the right and left of the genome, respectively 

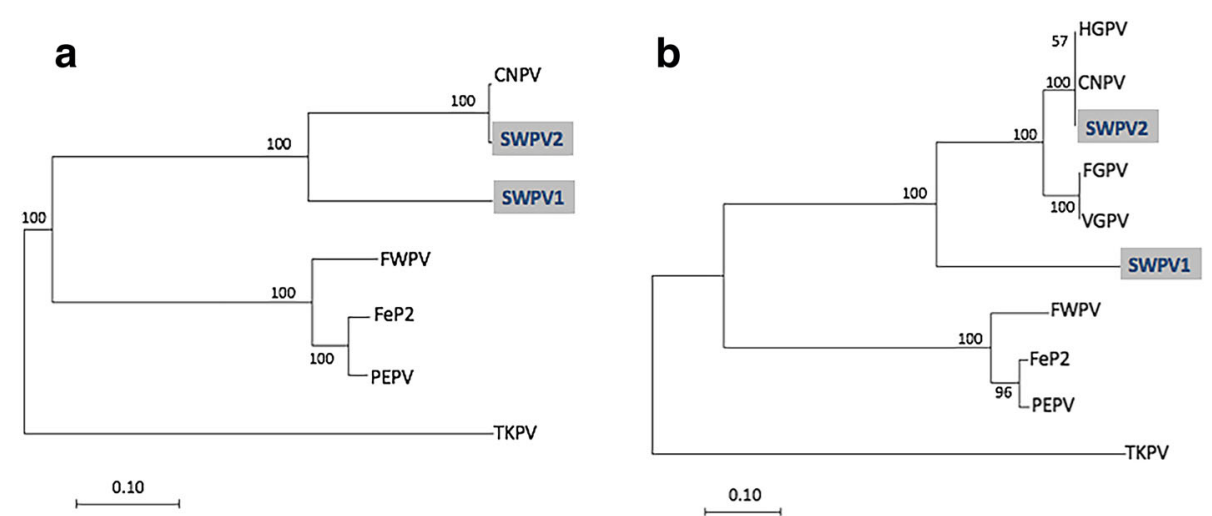

Fig. 3 Phylogenetic relationship between Shearwaterpox viruses (SWPV-1 and 2) and other avipoxviruses. a Phylogenetic tree of 173 kbp core region (large gaps removed) from available complete avipoxvirus genomes. b Phylogenetic tree highlighting viruses closely related to CNPV. The sequences were aligned with ClustalO and MEGA7 was used to create a maximum likelihood tree based on the Tamura-Nei method and tested by bootstrapping with 1000 replicates. The abbreviations and GenBank accession details for poxviruses strains were used: Canarypox virus (CNPV; AY318871), Pigeonpox virus (FeP2; KJ801920), Penguinpox virus (PEPV; KJ859677) Fowlpox virus (FWPV; AF198100), Shearwaterpox virus 1 (SWPV-1; KX857216), Shearwaterpox virus 2 (SWPV-2; KX857215), Turkeypox virus (TKPV; NC_028238), Vultur Gryphus poxvirus (VGPV; AY246559), Flamingopox virus (FGPV; HQ875129 and KM974726), Hawaiian goose poxvirus (HGPV; AY255628)

any sequences in the NR protein database using BLASTP. However, they are all relatively short ORFs and it is possible that they are not functional genes. Additionally, SWPV-1 encodes nine polypeptides that do not match CNPV proteins, but do match proteins from other avipoxviruses (penguinpox, turkeypox, pigeonpox and fowlpox). This could be due to recombination among ancestral viruses, but could also result from the loss of the corresponding ortholog in CNPV leaving another virus to provide the "best match".

As might be expected given the greater distance between SWPV-1 and CPNV than between SWPV-2 and $\mathrm{CNPV}$, there are more instances of minor rearrangements that created a loss of synteny (Table 1). However, since most of these involve the families of repeated genes, it is also possible that divergence of these

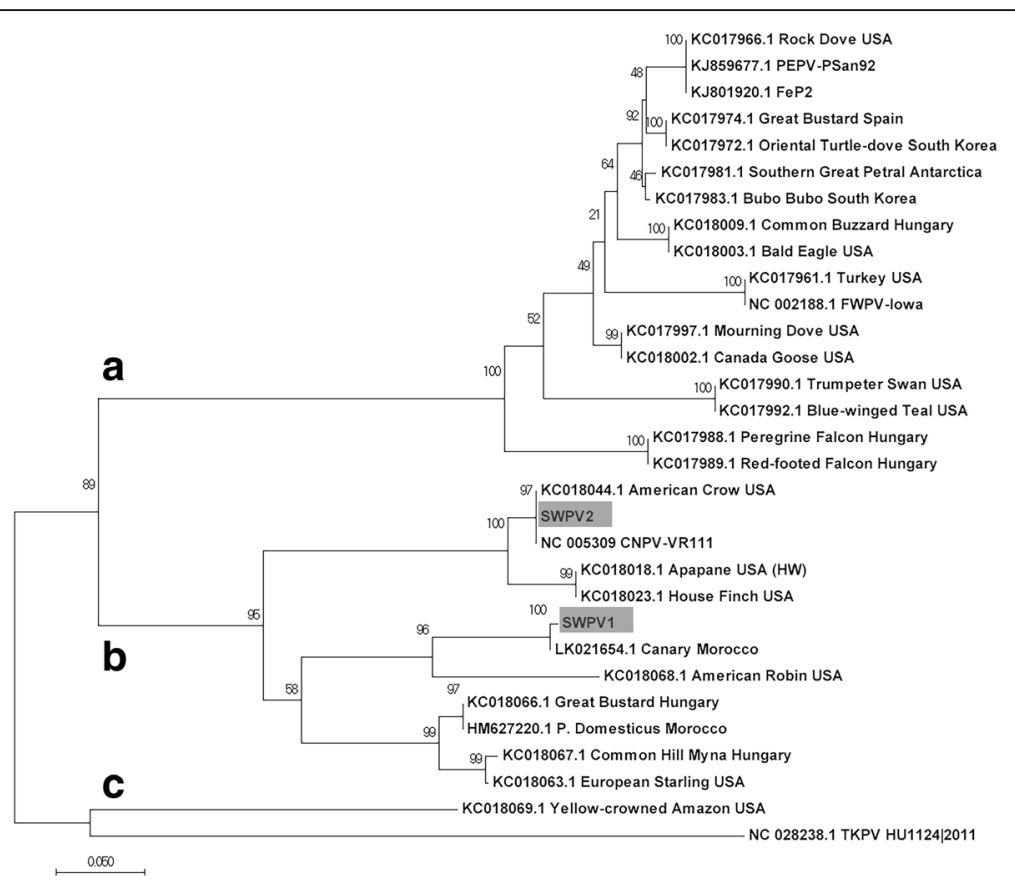

Fig. 4 Maximum likelihood phylogenetic tree from partial DNA sequences of p4b gene of avipoxviruses. Novel Shearwaterpox viruses (SWPV-1 and SWPV-2) are highlighted by gray background 


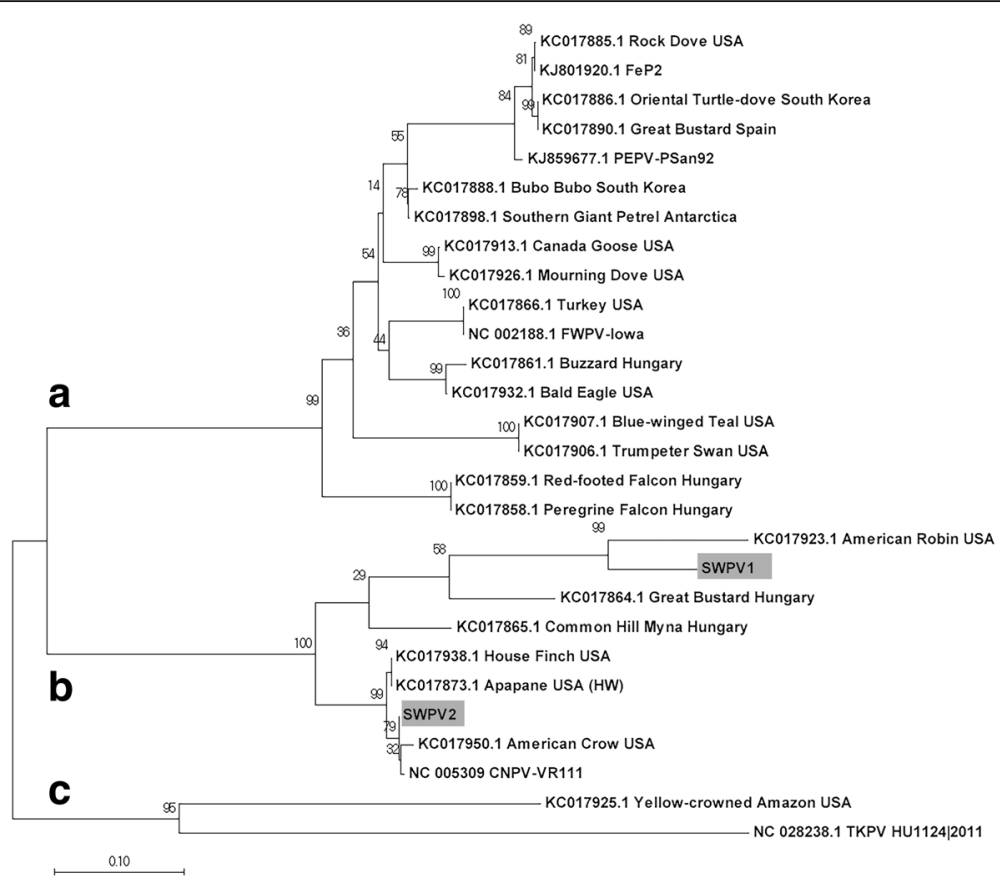

Fig. 5 Maximum likelihood phylogenetic tree from partial DNA sequences of DNA polymerase gene of avipoxviruses. Novel Shearwaterpox viruses (SWPV-1 and SWPV-2) are highlighted by gray background

sequences has led to the inability to distinguish between the orthologous and paralogous genes.

\section{Evidence of recombination among avipoxviruses}

When we reviewed a graph of nt identity between the 2 new complete genomes and CNPV using BBB (not shown), there were several relatively short syntenic regions where 1) SWPV-1 matched CNPV significantly better than the majority of the genome, and 2) SWPV2 matched CNPV significantly worse than the majority of the genome. To examine these regions in more detail, the Visual Summary feature of BBB was used to display individual SNPs for these genome comparisons (Fig. 6a and b). This analysis revealed that SWPV-1 and SWPV-2 were unique in these regions and confirmed that the genome sequences of SWPV-1and SWPV-2 were not contaminated during their assembly. However, when these regions were used as query sequences in BLASTN searches of all poxvirus sequences the best match remained CNPV suggesting that these sequences originated from avipoxvirus genomes that are not represented in the public databases.

\section{Discussion}

This paper describes the detection and characterization of two novel avipoxvirus complete genome sequences in a naturally occurring infections of avian pox in a naïve

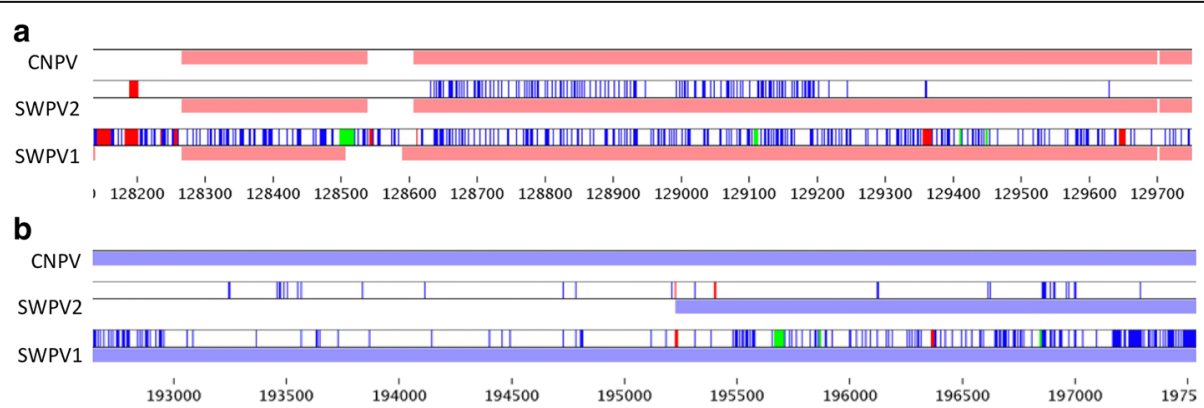

Fig. 6 Region of recombination in Shearwaterpox viruses (SWPV) detected in A. carneipes and A. pacificus. Nucleotide differences to CNPV are shown in blue (SNPs), green/red (indels). Figure 6a. Region of recombination in SWPV-2. On the middle track, SWPV-2 has very few differences to CNPV except for highly divergent block in the middle of this region. Figure 6b. Region of recombination in SWPV-1. On the bottom track, SWPV-1 is very different to CNPV except for highly similar block between nt 193,000 and 195,500 
population of shearwaters. The DNA sequences of SWPV-1 and SWPV-2 are significantly different than each other but nevertheless had closest similarity with Canarypox virus (67\% and 98\%, respectively). Furthermore, the genetic distance and novel genome structure of SWPV-1 from A. carneipes considered to be missing 43 genes likened to CNPV and contained 4 predicted genes which are not found in any other poxvirus and is overall sufficiently genetically different to be considered a separate virus species. Whilst, the SWPV-2 complete genome was missing 18 genes compared to CNPV, with a further 15 genes significantly fragmented as to probably cause them to be nonfunctional. Furthermore, the phylogenetic distribution of SWPV-1 indicates that shearwaters and perhaps other long-lived, vagile marine birds could be important hosts for avipoxvirus dispersal around the globe. The natural hosts of these avipoxviruses maybe this population of shearwaters, other migratory birds that use Lord Howe Island for breeding or resident avian host reservoir species. Species such as the Lord Howe White-eye (Zosterops tephropleura) and Lord Howe Golden Whistler (Pachcephala petoralis contempta) are candidate passerine birds that might provide such function.

Examining the phylogenetic relationship between the Shearwaterpox viruses and other avipoxviruses, it is evident that the SWPV-2 is most closely related to Canarypox virus. The SWPV-1 and SWPV-2 complete genomes both contain several genes that are more closely related to CNPV throughout their entire genome. As shown in Fig. 3 it is reasonable to postulate that these viruses originated from a common ancestor that diverged from a CNPV-like progenitor related to fowlpox, penguinpox and pigeonpox viruses. Finer resolution of the phylogenetic relationship using partial nucleotide sequences of $\mathrm{p} 4 \mathrm{~b}$ and DNA polymerase genes of avipoxviruses revealed that SWPV isolated from seabirds also clustered in global clade B consisting of avipoxviruses originating from Canary Morocco, Canarypox and poxviruses from American crow and American robin. Given their genetic diversity, it is perhaps not surprising that Shearwater species can be exposed to multiple avipoxviral infections. Studies such as those by Barnett et al. [25] suggest that the species specificity of poxviruses is variable. Some genera, such as Suipoxvirus are highly restricted to individual vertebrate hosts, swinepox for instance, whereas others, such as avipoxviruses demonstrate some evidence of cross-species infection within a predator-prey system [24]. This suggests that the avipoxviruses can infect a diverse range of bird species if they are within a close enough proximity to each other [26]. Thus far, there were no clear patterns regarding species-specificity in the Shearwaterpox viruses described here.
While overt and systemic lesions and fatal disease can occur, avian pox tends to be a self-limiting localized infection of apterial skin with full recovery possible. Many bird species experience life-long immunity if the immune system is not weakened and or the birds are not infected by different strains [27, 28]. As shown in our example, secondary infections can occur and these may contribute to morbidity and mortality [29-31]. Similar to the example in shearwaters, Shivaprasad et al. [30] reported evidence of poxvirus infection and secondary fungal pathogens in canaries (Serinus canaria). Stressful conditions, poor nutrition, overt environmental contamination and other underlying causes of immunosuppression and ill health may contribute to the pathogenesis of such lesions. This was the primary reason we tested for avian circovirus and other potential pathogens.

Avian pox has not been previously reported in shearwaters (Ardenna spp.) from Lord Howe Island, nor has it been documented for any other bird species in this region. So it is difficult to attribute the causality of this unique event in these species. The value of complete genome characterization and analysis is highlighted since a phylogenetic relationship based on single gene studies such as the polymerase gene may have falsely implicated Canarypox virus as a potential exotic introduced emerging disease from domesticated birds. Although we cannot trace the actual source of infection in the shearwater chicks, it is more likely that the infection in the birds resulted from parental feeding or arthropod mediated transmission from other island bird species [32]. While, the reservoir host of these novel Shearwaterpox viruses is unknown, mosquitoes are suspected to play a part in transmission within the island. Avipoxvirus infection appears to be relatively rare in seabirds, but it has been reported in several species when they occur on humaninhabited islands that harbor mosquito vectors [33]. According to the Lord Howe Island Board, ship rats, mice, cats, humans and other invasive pest species such as owls are implicated in the extinction of at least five endemic birds, two reptiles, 49 flowering plants, 12 vegetation communities and numerous threatened invertebrates [34]. These rodents and invasive pests have also been highlighted for the potential reservoir of poxvirus infections $[3,35]$. Transmission of avipoxvirus by prey-predator and other migratory seabirds likely plays a prominent role; however, the mode of avipoxvirus transmission on Lord Howe Island is not completely understood. Studies by Gyuranecz et al. [24], for example, postulated that raptors may acquire poxvirus infection from their avian prey. This suggests that the poxvirus in shearwaters is likely to be transmitted from other island species such as other 
migratory seabirds and/or prey-predator, although, it is difficult to be certain without further studies.

Interestingly, these new shearwaterpox virus complete genomes also provide evidence that supports the hypothesis that recombination may play an important role in the evolution of avipoxviruses. A number of genes in SWPV-1 appear to be rearranged compared to CNPV and blocks of unusual similarity scores were seen in both SWPVs. Software that is designed to look for gross recombination between two viruses, such as two strains of HIV, fails to detect this level of recombination and it is left to the investigator to observe such small events by eye after visualizing the distribution of SNPs between viruses. Such relatively small exchanges of DNA may still exert important influences on virus evolution, and has been predicted to have been a driver in the evolution of smallpox [36].

\section{Conclusions}

These are the first avipoxvirus complete genome sequences that infect marine bird species. The novel complete genome sequences of SWPV-1 and -2 have greatly enhanced the genomic information for the Avipoxvirus genus, which will contribute to our understanding of the avipoxvirus more generally, and track the evolution of poxvirus infection in such a non-model avian species. Together with the sequence similarities observed between SWPV and other avipoxviruses, this study concluded that the SWPV complete genome from A. carneipes (SWPV-1) described here is not closely related to any other avipoxvirus complete genome isolated from avian or other natural host species, and that it likely should be considered a separate species. Further investigations of Shearwaterpox viruses genetic and pathogenesis will provide a unique approach to better assess the risk associated to poxvirus transmission within and between marine bird species.

\section{Methods}

\section{Source of sampling}

A total of six samples were collected from two different species of shearwater, five were from Flesh-footed Shearwater (ID: 15-1527-31), and other one was from Wedge-tailed Shearwater (ID: 15-1526). Of size birds, two were recoded to have evidence of gross well circumscribed lesions in the beak (Fig. 1a) and ankle, and others had feather defects (fault lines across the vanes of feathers). Samples were collected from fledglings (approximately 80-90 days of age) of both species on Lord Howe Island, New South Wales (32.53S, 159.08E) located approximately $500 \mathrm{~km}$ off the east coast of Australia during April-May 2015. Samples were collected with the permission of the Lord Howe Island Board (permit no. LHIB 02/14) under the approval of the University of Tasmania and Charles Sturt University Animal Ethics Committees (permit no. A0010874, A0011586, and 09/046). Samples from one individual of each shearwater species were collected including skin lesions, liver and skin biopsies, as well as blood for identifying the causative agents. Depending on the samples, either $25 \mathrm{mg}$ of skin tissue were cut out and chopped into small pieces or $50-100 \mu \mathrm{L}$ of blood were aseptically transferred into clean $1.5 \mathrm{~mL}$ microcentrifuge tube (Eppendorf), and genomic DNA was isolated using the Qiagen blood and tissue mini kit (Qiagen, Germany). The extracted DNA has been stored at $-20^{\circ}$ $\mathrm{C}$ for further testing. Histopathological examination of the skin was performed.

\section{Archived viral and fungal pathogen testing}

Initially, the extracted DNA was screened for detecting novel circoviruses [37, 38] and reticuloendotheliosis virus [39]. For poxvirus screening, the primers PoxP1 (5'-CAGCAGGTGCTAAACAACAA-3') and PoxP2 (5'-CGGTAGCTTAACGCCGAATA-3') were synthesized from published literature and used to amplify a segment of approximately $578 \mathrm{bp}$ from the $4 \mathrm{~b}$ core protein gene for all ChPV species [40]. Optimized PCR reactions mixture contained $3 \mu \mathrm{L}$ of extracted genomic DNA, 25 pmol of each primer (GeneWorks, Australia), $1.5 \mathrm{mM} \mathrm{MgCl}_{2}, 1.25 \mathrm{mM}$ of each dNTP, $1 \mathrm{xGoTaq}^{\circ}$ Green Flexi Reaction Buffer, 1 U of Go Taq DNA polymerase (Promega Corporation, USA) and DEPC distilled $\mathrm{H}_{2} \mathrm{O}$ (Invitrogen, USA) was added to a final volume of $25 \mu \mathrm{L}$. The PCR amplification was carried out in an iCycler thermal cycler (Bio-Rad) under the following conditions: denaturation at $94{ }^{\circ} \mathrm{C}$ for $2 \mathrm{~min}$ followed by 35 cycles of $94{ }^{\circ} \mathrm{C}$ for $1 \mathrm{~min}, 60{ }^{\circ} \mathrm{C}$ for $1 \mathrm{~min}$ and $72{ }^{\circ} \mathrm{C}$ for $1 \mathrm{~min}$, and a final extension step of $2 \mathrm{~min}$ at $72^{\circ} \mathrm{C}$.

The internal transcribed spacer (ITS) region was chosen for screening and identification of fungal pathogens [41]. A set of fungus-specific primers ITS1 (5'TCCGTAGGTGAACCTGCGG -3') and ITS4 (5'TCCTCCGCTTATTGATATGC -3') were designed and used to amplify a segment of approximately $550 \mathrm{bp}$ from the fungal ITS gene [42]. The PCR was standardized to amplify ITS genes, and the $25-\mu \mathrm{L}$ reaction mixture contained $3 \mu \mathrm{L}$ of extracted genomic DNA, $25 \mathrm{pmol}$ of each primer (GeneWorks, Australia), $1.5 \mathrm{mM} \mathrm{MgCl}_{2}$, $1.25 \mathrm{mM}$ of each dNTP, $1 \mathrm{xGoTaq}^{\circ}$ Green Flexi Reaction Buffer, $1 \mathrm{U}$ of Go Taq DNA polymerase (Promega Corporation, USA). The PCR reaction involved initial denaturation at $95{ }^{\circ} \mathrm{C}$ for $5 \mathrm{~min}$, followed by 30 cycles of denaturation at $94{ }^{\circ} \mathrm{C}$ for $30 \mathrm{~s}$, annealing at $58{ }^{\circ} \mathrm{C}$ for $30 \mathrm{~s}$, and extension at $72{ }^{\circ} \mathrm{C}$ for $1 \mathrm{~min}$, and with a final step of one cycle extension at $72{ }^{\circ} \mathrm{C}$ for $10 \mathrm{~min}$. 
Amplified PCR products, together with a standard molecular mass marker (Sigma), were separated by electrophoresis in 2.0\% agarose gel and stained with GelRed (Biotium, CA). Selected bands were excised and purified using the Wizard ${ }^{\bullet}$ SV Gel and PCR Clean-Up System (Promega, USA) according to the manufacturer's instructions. Purified amplicons were sequenced with PCR primers by the Australian Genome Research Facility Ltd (Sydney) using an AB 3730xl unit (Applied Biosystems). For each amplicon, sequences were obtained at least twice in each direction for each isolate. The sequences were trimmed for primers and aligned to construct contigs (minimum overlap of $35 \mathrm{bp}$, minimum match percentage of 95\%) using Geneious Pro (version 10.0.2).

\section{High throughput sequencing}

Next-generation sequencing (NGS) was used to sequence the poxvirus genomes. Virion enrichment was performed by centrifugation for $2 \mathrm{~min}$ at $800 \times \mathrm{g}$ to remove tissue debris, and the supernatants were subsequently filtered through $5 \mu \mathrm{m}$ centrifuge filters (Millipore) [43]. The filtrates were nuclease treated to remove unprotected nucleic acids using $8 \mu \mathrm{L}$ RNase Cocktail Enzyme Mix (Invitrogen). Viral nucleic acids were subsequently extracted using QIAamp DNA mini (Qiagen). The genomic libraries were prepared with an insert size of 150 paired-end. DNA sequencing (NGS) was performed on a HiSeq4000 sequencing platform (Illumina) by Novogene, China.

\section{Bioinformatics}

Assembly of the viral genome was conducted according to the established pipeline [44] in CLC Genomics workbench 9.5.2 under La Trobe University Genomics Platform. Briefly, the preliminary quality evaluation for each raw read was generated using quality control (QC) report. The raw data were preprocessed to remove ambiguous base calls, and bases or entire reads of poor quality using default parameters. The datasets were trimmed to pass the quality control based on PHRED score or per base sequence quality score. Trimmed sequence reads were mapped against closely available host genome (Albatross) to remove possible remaining host DNA contamination, and post-filtered reads were mapped against reference Canarypox virus complete genome sequence. Consensus sequences were used to generate the complete poxvirus genome. Avipoxvirus complete genome sequences were aligned using MAFFT [45]. Then the poxvirus specific bioinformatics analyses were performed using the Viral Bioinformatics Resource Centre (virology.uvic.ca) [46], and the further analyses were conducted using the following tools: Viral Orthologous Clusters Database for sequence management (VOCs) [11]; Base-By-Base for genome/gene/protein alignments [47, 48]; Viral Genome Organizer for genome organization comparisons (VGO) [11], and Genome Annotation Transfer Utility for annotation (GATU) [49].

Open reading frames (ORFs) longer than 60 amino acids with minimal overlapping (overlaps cannot exceed $25 \%$ of one of the genes) to other ORFs were captured using the CLC Genomics Workbench (CLC) ORF analysis tool as well as GATU [49], and other protein coding sequence and annotation software described in Geneious (version 10.0.2, Biomatters, New Zealand). These ORFs were subsequently extracted into a FASTA file, and similarity searches including nucleotide (BLASTN) and protein (BLASTP) were performed on annotated ORFs as potential genes if they shared significant sequence similarity to known viral or cellular genes (BLAST E value $\leq \mathrm{e}-5$ ) or contained a putative conserved domain as predicted by BLASTp [50]. The final SWPV annotation was further examined with other poxvirus ortholog alignments to determine the correct methionine start site, correct stop codons, signs of truncation, and validity of overlaps.

\section{Phylogenetic analysis}

Phylogenetic analyses were performed using full poxvirus genome sequences for Shearwater species determined in this study with related avipoxvirus genome sequences available in GenBank database. A selection of partial sequences from seven completely sequenced avipoxvirus genomes and fragments of incompletely sequenced avipoxvirus genomes from Vultur Gryphus poxvirus (VGPV), flamingopox virus (FGPV) and Hawaiian goose poxvirus (HGPV) were also used for phylogenetic analysis. To investigate closer evolutionary relationship among avipoxviruses, partial nucleotide sequences of $\mathrm{p} 4 \mathrm{~b}$ and DNA polymerase genes were selected. The avipoxvirus sequences were aligned using ClustalO, and then manually edited in Base-by-Base. MEGA7 was used to create a maximum likelihood tree based on the Tamura-Nei method and tested by bootstrapping with 1000 replicates. An additional analysis was performed using complete genome nucleotide sequences of Canarypox virus (CNPV; AY318871), Pigeonpox virus (FeP2; KJ801920), Fowlpox virus (FPV; AF198100), Turkeypox virus (TKPV; NC_028238), Shearwaterpox virus strain-1 (SWPV-1; KX857216), and Shearwaterpox virus strain-2 (SWPV-2; KX857215), which were aligned with MAFTT in Base-By-Base for genome/gene/ protein alignments [48]. The program jModelTest 2.1.3 favoured a general-time-reversible model with gamma distribution rate variation and a proportion of invariable sites (GTR + I + G4) for the ML analysis [51]. 


\section{Additional files}

Additional file 1: Table S1. Summary of SWPV1 genome annotations (DOCX $52 \mathrm{~kb}$ )

Additional file 2: Table S2. Summary of SWPV2 genome annotations (DOCX $145 \mathrm{~kb})$

\section{Abbreviations}

ChPV: Chordopoxvirinae; CNPV: Canarypox virus; dsDNA: double-stranded; FGPV: Flamingopox virus; FP9: European strain of Fowlpox virus; FPVUS: South African strain of Fowlpox virus; GATU: Genome Annotation Transfer Utility; HGPV: Hawaiian goose poxvirus; ITS: internal transcribed spacer; ML: Maximum likelihood; NGS: Next-generation sequencing; ORF: open reading frame; PCR: polymerase chain reaction; PEPV: Penguinpox virus; QC: Quality control; SWPV-1: Shearwaterpox virus 1; SWPV-2: Shearwaterpox virus 2; TKPV: Turkeypox virus

\section{Acknowledgments}

The authors are extremely grateful to La Trobe University School of Life Science Publication Booster Award for their financial support to SS. Additional funding for this project was generously provided by the Detached Foundation, Trading Consultants Ltd, and L. Bryce. Assistance in the field was provided by the Lord Howe Island community and numerous dedicated volunteers, particularly A. Fidler, P. Lewis, A. Lombal, K. Richards, and $\mathrm{V}$. Wellington. The authors thank Chad Smithson for help with genome assembly.

\section{Funding}

Funding for this project was generously provided by the Detached Foundation, Trading Consultants Ltd, and L. Bryce. However, none of these have grant numbers assigned since all are donations from private philanthropists. Additional financial support was provided to SS through the La Trobe University School of Life Science Publication Booster Award. CU and II were funded by the Natural Sciences and Engineering Research Council of Canada (NSERC) Discovery Grant. The funding bodies had no role in the design of the study and collection, analysis, and interpretation of data and in writing the manuscript.

\section{Availability of data and materials}

The complete genome sequences of the Shearwaterpox virus 1 from a Fleshfooted Shearwater (Ardenna carneipes) and Shearwaterpox virus 2 from a Wedge-tailed Shearwater (Ardenna pacificus) have been deposited in the NCBI database under GenBank accession numbers: [SWPV-1, GenBank: KX857216] and [SWPV-2, GenBank: KX857215].

\section{Authors' contributions}

Conceived and designed the experiments: SS, SRR. Performed the experiments: SS, SRR. Analyzed the data: SS, CU, JI, SRR. Contributed reagents/materials/analysis tools: SS, SD, JLL, IH, KH, CU, JI, SRR. SS, JLL, CU, JI, SRR wrote the initial manuscript. All authors read, edited and approved the final manuscript.

\section{Competing interests}

The authors declare that they have no competing interests.

\section{Consent for publication}

Not applicable.

\section{Ethics approval}

Samples were collected with the permission of the Lord Howe Island Board (permit no. LHIB 02/14) under the approval of the University of Tasmania and Charles Sturt University Animal Ethics Committees (permit no. A13836, A0010874, A0011586, and 09/046).

\section{Publisher's Note}

Springer Nature remains neutral with regard to jurisdictional claims in published maps and institutional affiliations.

\section{Author details}

'Department of Physiology, Anatomy and Microbiology, School of Life Sciences, La Trobe University, Melbourne, VIC 3086, Australia. ${ }^{2}$ School of Animal and Veterinary Sciences, Charles Sturt University, Wagga Wagga, NSW 2678, Australia. ${ }^{3}$ Institute for Marine and Antarctic Studies, University of Tasmania, Hobart, TAS 7004, Australia. ${ }^{4}$ Lord Howe Island Museum, Lord Howe Island, NSW 2898, Australia. ${ }^{5}$ Department of Biochemistry and Microbiology, University of Victoria, Victoria, BC, Canada.

Received: 18 December 2016 Accepted: 5 April 2017

Published online: 13 April 2017

\section{References}

1. Bolte AL, Meurer J, Kaleta EF. Avian host spectrum of avipoxviruses. Avian Pathol. 1999;28(5):415-32.

2. van Riper C, Forrester DJ. Avian Pox. In: Thomas NJ, Hunter DB, Atkinson $\mathrm{CT}$, editors. Infectious diseases of wild birds. Oxford: Wiley Blackwell Publishing; 2007.

3. Offerman K, Carulei O, van der Walt AP, Douglass N, Williamson A-L. The complete genome sequences of poxviruses isolated from a penguin and a pigeon in South Africa and comparison to other sequenced avipoxviruses. BMC Genomics. 2014;15(1):1-17.

4. Atkinson CT, LaPointe DA. Introduced avian diseases, climate change, and the future of Hawaiian Honeycreepers. J Avian Med Surg. 2009:23(1):53-63.

5. Alley MR, Hale KA, Cash W, Ha HJ, Howe L. Concurrent avian malaria and avipox virus infection in translocated South Island saddlebacks (Philesturnus carunculatus carunculatus). N Z Vet J. 2010;58(4):218-23.

6. Gubser C, Hué S, Kellam P, Smith GL. Poxvirus genomes: a phylogenetic analysis. J Gen Virol. 2004;85(1):105-17.

7. Afonso CL, Tulman ER, Lu Z, Zsak L, Kutish GF, Rock DL. The genome of fowlpox virus. J Virol. 2000;74(8):3815-31.

8. Laidlaw SM, Skinner MA. Comparison of the genome sequence of FP9, an attenuated, tissue culture-adapted European strain of Fowlpox virus, with those of virulent American and European viruses. J Gen Virol. 2004;85(Pt 2):305-22.

9. Tulman ER, Afonso CL, Lu Z, Zsak L, Kutish GF, Rock DL. The Genome of Canarypox Virus. J Virol. 2004;78(1):353-66

10. Banyai K, Palya V, Denes B, Glavits R, Ivanics E, Horvath B, Farkas SL, Marton S, Balint A, Gyuranecz M, et al. Unique genomic organization of a novel Avipoxvirus detected in turkey (Meleagris gallopavo). Infect Genet Evol. 2015;35:221-9.

11. Upton C, Slack S, Hunter AL, Ehlers A, Roper RL. Poxvirus Orthologous Clusters: toward Defining the Minimum Essential Poxvirus Genome. J Virol. 2003;77(13):7590-600.

12. Croxall JP, Butchart SHM, Lascelles BEN, Stattersfield AJ, Sullivan BEN, Symes A, Taylor P. Seabird conservation status, threats and priority actions: a global assessment. Bird Conserv Int. 2012;22(1):1-34

13. Reid T, Hindell M, Lavers JL, Wilcox C. Re-examining mortality sources and population trends in a declining seabird: using Bayesian methods to incorporate existing information and new data. PLoS One. 2013;8(4):e58230.

14. Bond $\mathrm{AL}$, Lavers JL. Trace element concentrations in feathers of flesh-footed shearwaters (Puffinus carneipes) from across their breeding range. Arch Environ Contam Toxicol. 2011;61(2):318-26.

15. Illera JC, Emerson BC, Richardson DS. Genetic characterization, distribution and prevalence of avian pox and avian malaria in the Berthelot's pipit (Anthus berthelotii) in Macaronesia. Parasitol Res. 2008;103(6):1435-43.

16. Lecis R, Secci F, Antuofermo E, Nuvoli S, Scagliarini A, Pittau M, Alberti A. Multiple gene typing and phylogeny of avipoxvirus associated with cutaneous lesions in a stone curlew. Vet Res Commun. 2017:4:1-7.

17. Woolaver LG, Nichols RK, Morton ES, Stutchbury BJM. Population genetics and relatedness in a critically endangered island raptor, Ridgway's Hawk Buteo ridgwayi. Conserv Genet. 2013;14(3):559-71.

18. Thiel T, Whiteman NK, Tirape A, Baquero Ml, Cedeno V, Walsh T, Uzcategui GJ, Parker PG. Characterization of canarypox-like viruses infecting endemic birds in the Galapagos Islands. J Wildl Dis. 2005;41(2):342-53.

19. van Riper C, van Riper SG, Hansen WR. Epizootiology and Effect of Avian Pox on Hawaiian Forest Birds. Auk. 2002;119(4):929-42.

20. Young LC, VanderWerf EA. Prevalence of avian pox virus and effect on the fledging success of Laysan Albatross. J Field Ornithol. 2008;79(1):93-8.

21. Hane JK, Lowe RG, Solomon PS, Tan KC, Schoch CL, Spatafora JW Crous PW, Kodira C, Birren BW, Galagan JE, et al. Dothideomycete plant 
interactions illuminated by genome sequencing and EST analysis of the wheat pathogen Stagonospora nodorum. Plant Cell. 2007;19(11):3347-68.

22. Ghikas DV, Kouvelis VN, Typas MA. The complete mitochondrial genome of the entomopathogenic fungus Metarhizium anisopliae var. anisopliae: gene order and trn gene clusters reveal a common evolutionary course for all Sordariomycetes, while intergenic regions show variation. Arch Microbiol. 2006;185(5):393-401.

23. Le Loc'h G, Ducatez MF, Camus-Bouclainville C, Guérin J-L, Bertagnoli S. Diversity of avipoxviruses in captive-bred Houbara bustard. Vet Res. 2014;45(1):98.

24. Gyuranecz M, Foster JT, Dán Á, Ip HS, Egstad KF, Parker PG, Higashiguchi JM, Skinner MA, Höfle U, Kreizinger Z, et al. Worldwide Phylogenetic Relationship of Avian Poxviruses. J Virol. 2013;87(9):4938-51.

25. Barnett J, Dastjerdi A, Davison N, Deaville R, Everest D, Peake J, Finnegan C, Jepson P, Steinbach F. Identification of Novel Cetacean Poxviruses in Cetaceans Stranded in South West England. PLoS One. 2015;10(6):e0124315.

26. Haller SL, Peng C, McFadden G, Rothenburg S. Poxviruses and the Evolution of Host Range and Virulence. Infect Genet Evol. 2014;21:15-40.

27. EAZWV Transmissible Disease Fact Sheet. http://c.ymcdn.com/sites/www. eazwv.org/resource/resmgr/Files/Transmissible_Diseases_Handbook/Fact_ Sheets/006_Avian_Pox.pdf. Accessed 18 Jan 2016.

28. Winterfield RW, Reed W. Avian pox: infection and immunity with quail, psittacine, fowl, and pigeon pox viruses. Poult Sci. 1985;64(1):65-70.

29. Johnson BJ, Castro AE. Canary pox causing high mortality in an aviary. J Am Vet Med Assoc. 1986;189(10):1345-7.

30. Shivaprasad HL, Kim T, Tripathy D, Woolcock PR, Uzal F. Unusual pathology of canary poxvirus infection associated with high mortality in young and adult breeder canaries (Serinus canaria). Avian Pathol. 2009;38(4):311-6.

31. Reza K, Nasrin A, Mahmoud S. Clinical and pathological findings of concurrent poxvirus lesions and aspergillosis infection in canaries. Asian Pac J Trop Biomed. 2013;3(3):182-5.

32. Shearn-Bochsler V, Green DE, Converse KA, Docherty DE, Thiel T, Geisz HN, Fraser WR, Patterson-Fraser DL. Cutaneous and diphtheritic avian poxvirus infection in a nestling Southern Giant Petrel (Macronectes giganteus) from Antarctica. Polar Biol. 2008;31(5):569-73.

33. VanderWerf EA, Young LC. Juvenile survival, recruitment, population size, and effects of avian pox virus in Laysan Albatross (Phoebastria immutabilis) on Oahu, Hawaii, USA. The Condor. 2016;118(4):804-14.

34. Lord Howe Island Board. http://www.Ihib.nsw.gov.au/environment/ biodiversity/research. Accessed 20 Sep 2016.

35. Tantawi HH, Zaghloul TM, Zakaria M. Poxvirus infection in a rat (Rattus norvegicus) in Kuwait. Int J Zoonoses. 1983;10(1):28-32.

36. Smithson C, Purdy A, Verster AJ, Upton C. Prediction of Steps in the Evolution of Variola Virus Host Range. PLoS One. 2014;9(3):e91520.

37. Sarker S, Lloyd C, Forwood J, Raidal SR. Forensic genetic evidence of beak and feather disease virus infection in a Powerful Owl. Ninox strenua Emu. 2016;116(1):71-4.

38. Sarker S, Moylan KG, Ghorashi SA, Forwood JK, Peters A, Raidal SR. Evidence of a deep viral host switch event with beak and feather disease virus infection in rainbow bee-eaters (Merops ornatus). Sci Rep. 2015;5:14511.

39. Biswas SK, Jana C, Chand K, Rehman W, Mondal B. Detection of fowl poxvirus integrated with reticuloendotheliosis virus sequences from an outbreak in backyard chickens in India. Vet Ital. 2011;47(2):147-53.

40. Huw Lee L, Hwa Lee K. Application of the polymerase chain reaction for the diagnosis of fowl poxvirus infection. J Virol Methods. 1997;63(1-2):113-9.

41. Kumar M, Shukla PK. Use of PCR Targeting of Internal Transcribed Spacer Regions and Single-Stranded Conformation Polymorphism Analysis of Sequence Variation in Different Regions of rRNA Genes in Fungi for Rapid Diagnosis of Mycotic Keratitis. J Clin Microbiol. 2005;43(2):662-8.

42. Lindsley MD, Hurst SF, lqbal NJ, Morrison CJ. Rapid Identification of Dimorphic and Yeast-Like Fungal Pathogens Using Specific DNA Probes. J Clin Microbiol. 2001:39(10):3505-11.

43. Jensen RH, Mollerup S, Mourier T, Hansen TA, Fridholm H, Nielsen LP, Willerslev E, Hansen AJ, Vinner L. Target-dependent enrichment of virions determines the reduction of high-throughput sequencing in virus discovery. PLoS One. 2015;10(4):e0122636

44. Zhao K, Wohlhueter RM, Li Y. Finishing monkeypox genomes from short reads: assembly analysis and a neural network method. BMC Genomics. 2016;17 Suppl 5:497.

45. Katoh K, Misawa K, Kuma K, Miyata T. MAFFT: A novel method for rapid multiple sequence alignment based on fast Fourier transform. Nucleic Acids Res. 2002;30(14):3059-66.
46. Ehlers A, Osborne J, Slack S, Roper RL, Upton C. Poxvirus Orthologous Clusters (POCs). Bioinformatics. 2002;18(11):1544-5.

47. Brodie R, Smith AJ, Roper RL, Tcherepanov V, Upton C. Base-By-Base: Single nucleotide-level analysis of whole viral genome alignments. BMC Bioinformatics. 2004;5(1):1-9.

48. Hillary W, Lin S-H, Upton C. Base-By-Base version 2: single nucleotide-level analysis of whole viral genome alignments. Microb Inf Exp. 2011;1:2-2.

49. Tcherepanov V, Ehlers A, Upton C. Genome Annotation Transfer Utility (GATU): rapid annotation of viral genomes using a closely related reference genome. BMC Genomics. 2006;7(1):1-10.

50. Benson DA, Cavanaugh M, Clark K, Karsch-Mizrachi I, Lipman DJ, Ostell J, Sayers EW. GenBank. Nucleic Acids Res. 2013;41(Database issue):D36-42.

51. Darriba D, Taboada GL, Doallo R, Posada D. jModelTest 2: more models, new heuristics and parallel computing. Nat Methods. 2012;9(8):772-2

\section{Submit your next manuscript to BioMed Central and we will help you at every step:}

- We accept pre-submission inquiries

- Our selector tool helps you to find the most relevant journal

- We provide round the clock customer support

- Convenient online submission

- Thorough peer review

- Inclusion in PubMed and all major indexing services

- Maximum visibility for your research

Submit your manuscript at www.biomedcentral.com/submit 